\title{
GCU
}

Glasgow Caledonian

University

University for the Common Good

\section{Kanchanaburi and the Thai-Burma Railway: disputed narratives in the interpretation of War}

Lennon, John

Published in:

International Journal of Tourism Cities

DOI:

10.1108/IJTC-06-2017-0033

Publication date:

2018

Document Version

Author accepted manuscript

Link to publication in ResearchOnline

Citation for published version (Harvard):

Lennon, J 2018, 'Kanchanaburi and the Thai-Burma Railway: disputed narratives in the interpretation of War', International Journal of Tourism Cities , vol. 4, no. 1, pp. 140-155. https://doi.org/10.1108/IJTC-06-2017-0033

\section{General rights}

Copyright and moral rights for the publications made accessible in the public portal are retained by the authors and/or other copyright owners and it is a condition of accessing publications that users recognise and abide by the legal requirements associated with these rights.

Take down policy

If you believe that this document breaches copyright please view our takedown policy at https://edshare.gcu.ac.uk/id/eprint/5179 for details of how to contact us. 
Kanchanaburi and the Thai-Burma Railway: disputed narratives in the interpretation of War

\begin{abstract}
This paper considers the history and dark tourism attractions associated with a case study of the Thai-Burma Railway in the city of Kanchanaburi, Thailand. The paper considers how history has been abridged and distorted at a number of attraction sites in order to exploit the dark tourism commercial potential. The role of film media is considered as a critical element of the site narrative and the reality of the tragic past of this place is discussed within the context of Thailand's role in World War Two. This is the first time the heritage of this city has been considered in the context of dark tourism and the role of Thailand in World War Two. It incorporates an analysis of all of the relevant attractions in the city and provides through the fieldwork conducted an original contribution to the tourism literature in this field. Kanchanaburi, through the urban attractions that constitute the primary motivations for visitation, distorts and exploits its dark history for commercial and ideological purposes. Where accurate World War Two interpretation was identified, it was maintained by balancing the requirements of national governments and institutions with acceptable levels of ambiguity and non-controversial perspectives on this urban location's dark past.
\end{abstract}




\section{Introduction and Context}

The city of Kanchanaburi, located in the province of the same name in north east Thailand on the border with Myanmar is not a first stop destination for inbound tourists to Thailand. Indeed, Thailand offers the international visitor many alternative attractions, activities and contrasting experiences. Thailand welcomed more than29.9 million international visitors in 2015 and achieving an enviable $6^{\text {th }}$ place in the world in terms of tourism expenditure. Performance of the nation across the years $2012-15$ is detailed below.

\begin{tabular}{|l|l|l|l|l|}
\hline & $\mathbf{2 0 1 2}$ & $\mathbf{2 0 1 3}$ & $\mathbf{2 0 1 4}$ & $\mathbf{2 0 1 5}$ \\
\hline International Visitor & 22,308 & 26,547 & 24,810 & 29,881 \\
Arrivals (m) & & & & \\
\hline \% Growth & & $18.8 \%$ & $-6.5 \%$ & $20.4 \%$ \\
\hline
\end{tabular}

Table 1.0 : International Arrivals Thailand 2012-2015 (Source: UNWTO, 2016)

The primary pull factor remains the capital; Bangkok, with $21.9 \mathrm{~m}$ overnight visitors. This is followed by the beach locations of Phuket and Pattay City achieving $9.3 \mathrm{~m}$ and $8.1 \mathrm{~m}$ visitors respectively in 2015 (TAT, 2016). In contrast, Kanchanaburi, capital of Kanchanaburi Province, with a population of 31,327 , remains much less visited. The province is in the west of Thailand, $129 \mathrm{~km}$ from Bangkok, and covers a total area of approximately $19,483 \mathrm{~km}^{2}$ and is the country's third largest province.

In recent years, Kanchanaburi has seen some growth in short break tourism, predominantly by Thai nationals, travelling north from the urban sprawl of Bangkok, to the closest significant natural heritage destination. Kanchanaburi benefits from proximity to two major national parks in this part of Thailand:

- Erawan National Park (with its celebrated seven cascading waterfalls)

- Sai Yok National Park (bordering Myanmar) 
However, for the majority of international tourists the primary attraction to this destination relates to the Thai-Burma Railway history and its representation in the city. The location has become synonymous with the railway and the 'bridge' over the River' Kwai' and a period of Second World War history made famous by filmic entertainment rather than historical narrative. It is now seen as a destination associated with dark tourism wherein key attractions and sites have become a primary motivation for visitation.

\section{Dark Tourism and destinations associated with a tragic past}

Dark tourism (sometimes referred to as thanatourism) has become established since 1996 as a specialist area of tourism study. Death, suffering, visitation, and tourism have been interrelated for many centuries, but the phenomena was identified as such and categorized by Lennon and Foley in 1996 and was later the subject of the defining source text: Dark Tourism: The Attraction of Death and Disaster (Lennon and Foley, 2000).

The phenomenon exists across a range of destinations and demonstrates commonality and unifying elements in a variety of locations and political regimes. These dark tourism sites act as the meeting place for history and visitation where questions of authenticity and fact are sometimes juxtaposed with the operation of tourism facilities. What is celebrated, interpreted, and developed is often selective, and dilemmas of commemoration are reflected in the condition, nature, and content of these sites. The tourist attractions at such sites become key physical elements of heritage either authentic or created that combines in whole or part: commemoration, history, and record. Dark tourism attractions demonstrate demand from consumers for this type of experience. However, they also constitute commemoration, historical reference, narrative legacies, and can 
constitute populist visitor experiences. These tourism sites in some cases become one of the few remaining commemorative elements of victims and their testimonies. In such cases the content and its narrative interpretation take on critically important values in understanding a shared dark past.

For many years, humans have been attracted to sites and events that are associated with death, disaster, suffering, violence, and killing. From ancient Rome and gladiatorial combat to attendance at public executions in London and other major cities of the world, death has held an appeal. Sites associated with death and disaster seem to exert a dark fascination for visitors and are frequently linked to crime locations and the perpetration of both lawful and unlawful acts (Lennon, 2010). The sheer diversity of forms of dark tourism sites is significant and has been the subject of research (see, e.g., Lennon \& Foley, 1996, 2000; Seaton, 1996; Seaton \&,Lennon, 2004; Dann \& Seaton, 2001; Ashworth, 1996; Sharpley \&,Stone 2009).

Further useful contributions to the area include issues of interpretation and selective commemoration (White \& Frew, 2012), cross-disciplinary studies in the field of the sociology of death and death studies (Mitchell, 2007), literature and writing (Skinner, 2012), problematic heritage (Ashworth, 1996, Tunbridge \& Ashworth, 1995), the area of criminology/crime sites (Botterill \& Jones, 2010), the architectural legacy of dark sites (Philpott, 2016) and in development of scales of dark heritage (Sharpley and Stone 2009).

Tourism and death enjoy a curious relationship. Death and acts of mass killing are a major deterrent for the development of certain destinations, and yet such acts can become the primary purpose of visitation in others. In the literature that has emerged since identification and analysis of the phenomenon dark tourism sites have been identified as destination 'pull' factors, and the relationship between crime and its attraction to visitors has been explored ( Dalton 2015). The consideration to date has included:

- Visits to death sites and disaster scenes (whether real or created)

- Visits to sites of mass or individual death 
- Visits to sites of incarceration

- Visits to representations or simulations associated with death

- Visits to re-enactments and human interpretations of death

Murder, execution, and sites of lawful and unlawful deaths have served to attract the attention of visitors and residents from ancient times to the current day. The city of Kanchanaburi offers further evidence of the phenomenon. In this context and in other cases education and the nature of the learning experience are frequently used to justify and explain motivation for development and visitation in the modern world. Indeed, the idea of travel as an educational experience of new and previously unvisited destinations is frequently used as a rational argument associated with discussions of modernity. More recently, it is the significance of film, television and communications technology, reporting, and real-time communication that serves to heighten awareness of dark destinations that may be visited. Once again the Thai-Burma Railway and its association with iconic filmic representation has clear relevance in this context which is explored further below.

\section{Methodology}

The paper draws on literature, historical documents and tourism publications related to World War Two and the incarceration and forced labour associated with the Thai-Burma Railway and the city of Kanchanaburi . Fieldwork incorporating tourist attraction and commemorative site visitation was undertaken in Norther Thailand in January 2017. Curators, managers, operators and tourist authorities were contacted in advance of the fieldwork by email to request interviews. The sites 
identified were the primary sites visited by tourists and no related World War Two site in the area was excluded . In just less than half of the cases of requests, subjects were unwilling to participate. For those interviewed in relation to the subject area, a standard questionnaire based on a rolling data base, relevant to particular sites was utilised. Where permitted interviews were taped and transcribed. It should be noted that the subject area was seen as sufficiently sensitive by the majority of those contacted that audio recording was deemed unacceptable. The data below has been assembled to provide a perspective on what is both a historically problematic and ideologically conflicted use of the narrative of the part of the Second World War and its problematic exploitation.

\section{Understanding the historical context}

This area of Thailand was an important part of the narrative of the Second World War and Japan's struggle for dominance in this part of Asia. The outbreak of hostilities in December 1941 with the simultaneous attacks on Pearl Harbour and British colonies saw the Japanese invasion of the Malayan peninsula with the goal of capturing Singapore. In February, 1942, the fall of Singapore saw the surrender and capture of an enormous number of allied prisoners. In total some; 28,500 British, 18,000 Australians, 67,000 Indians and 14,000 local volunteers surrendered to the Japanese. This significant volume of manpower was later to be deployed in the construction of the Thai - Burma railway sometimes referred to as the 'Death Railway'. Burma was an important invasion target for the Japanese since it provided a critical allied supply chain to their adversary China. However, Burma also offered access to raw materials for the Japanese war machine hence, some form of rail link between Thailand and Burma was considered a necessity. 
It is important to note that during the Second World War, Thailand signed a co-operation agreement with the Japanese government in January 1942, declaring war on both America and Britain only days later. However, as the conflict in WW2 progressed, the co-operation agreement assumed many of the characteristics of an occupation (Thompson, 2002). At a national level there is significant sensitivity about this period of Thai history and as Beaumont $(2012,26)$ noted:

“...there has been something of a national amnesia about the Thai's bystander role as war crimes were committed on their territory."

This selective attention to the history of conflict and state actions is not unique to Thailand and characterises the way many governments and nations re-represent their past. For further discussion see Lowenthal (1997) and for a comparable example in the case of Lithuania, during the Second World War, see Lennon and Wight (2008). In the case of Thailand, the events of late 1942 were critical in understanding the extent of this process of re-representation of history. Japan ordered the development of a Thai- Burma railway in 1942-3, given Allied pressure on sea based supply chains. Japan had conquered much of South East Asia within six months of the Pearl Harbour attack on December 1941 (Beattie, 2015). However, the defeat of the Japanese Navy at the Battle of Midway in 1942 resulted in major supply chain problems for Japanese troops located in Burma and the importance of a potential rail link became highly significant. The railway construction of such a route was not feasible with heavy construction plant and machinery which was impossible to transport to the site given the terrain and climate (Thompson, 2002). Accordingly, the $415 \mathrm{~km}$ railway from Bampong (Thailand) to Thanbyuzayay ( Burma) was to be constructed by Asian 
labourers and Allied prisoners of war.

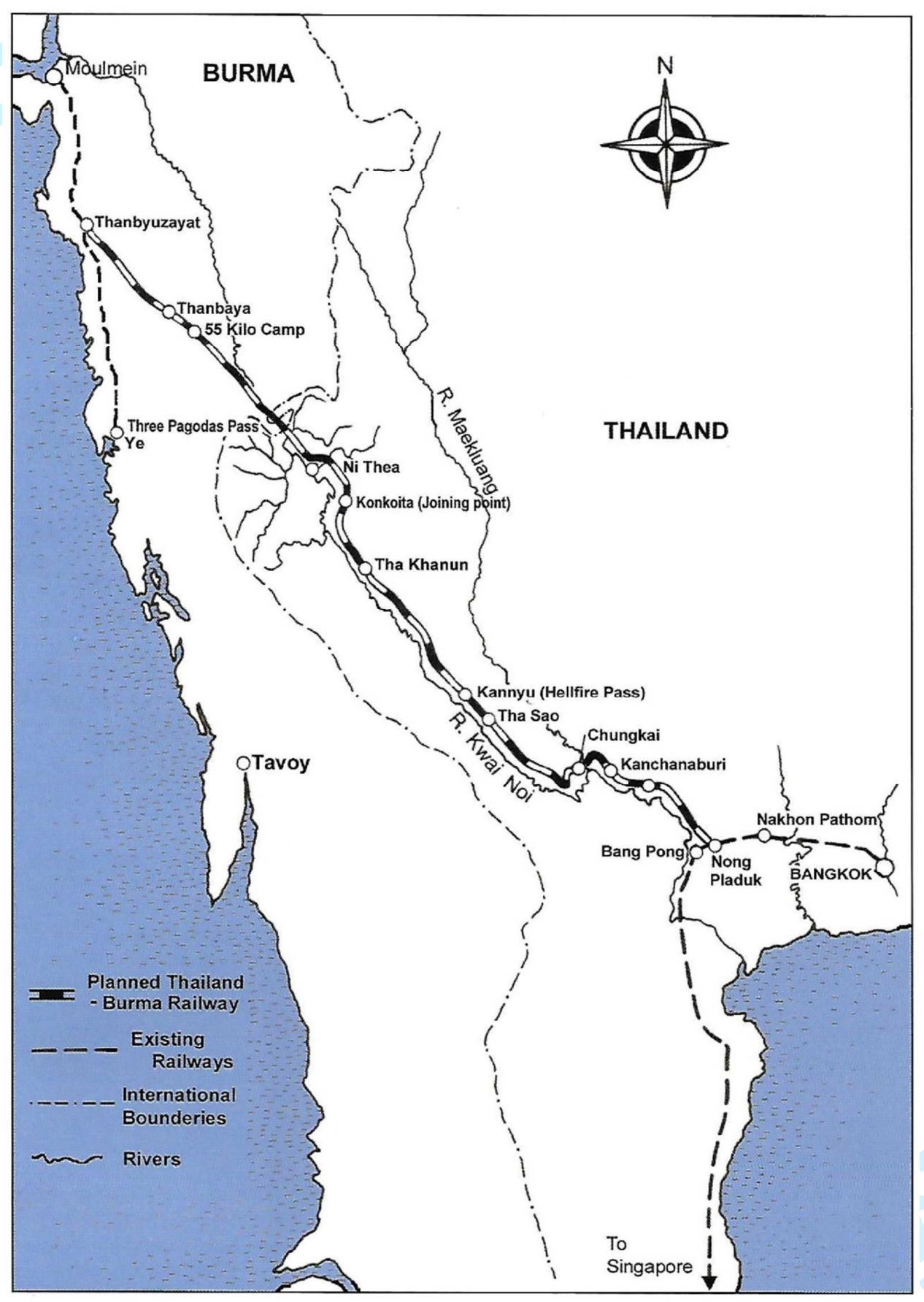

Diagram 1.0: Map of Route of Thai-Burma Railway 1942-43 (Source: Australian-Thailand Chamber of Commerce 2006) 
The large number of allied POWs and the indigenous populations of some of the Japanese occupied Asian nations provided the forced labour supply. The railway was to cross a range of rivers, coastal plains, foothills and inaccessible mountainous border regions. The latter terrain often required deep cuttings into solid rock, large embankments and numerous wooden trestle bridges (Kinvig, 1992). Much of this difficult construction work was undertaken by hand by POWs and Asian forced labour, using tap drills and explosives. Forest was cleared and earth was moved manually at significant human cost (Hardie, 1983). The use of prisoners of war in such dangerous tasks, assisting their captor's in the war effort, was directly in contravention with the Geneva Convention. However, as a non-signatory Japan choose to deploy large numbers of allied prisoners in this task. The prison workforce was extended significantly by the use of Asian labourers (predominantly Malays, Tamils and Burmese). In total across the duration of the construction the workforce consisted of circa 330,000 including some 61,000 Prisoners of War (Australian -Thai Chamber of Commerce, 2007) as detailed below.

\begin{tabular}{|l|l|l|}
\hline Nationality & Employed on Thai - Burma Railway & Deaths \\
Origin (including & 75,000 & 42,000 \\
Malays, Tamils and & & \\
Chinese) & & \\
\hline Burmese & Initial Japanese draft circa 175,000 & 40,000 (does not include \\
& Following desertion & deaths of those who \\
\hline British & 90,000 & deserted) \\
\hline
\end{tabular}




\begin{tabular}{|l|l|l|}
\hline Javanese & 7,500 & 2,900 \\
\hline Australian & 13,004 & 2,710 \\
\hline Dutch & 17,990 & 2,737 \\
\hline Chinese (Singapore) & 5,200 & 500 \\
\hline America & 686 & 132 \\
\hline Aminese & 200 & 25 \\
\hline TOTAL & $\mathbf{2 3 9 , 7 1 1}$ & $\mathbf{9 7 , 6 5 2}$ \\
\hline
\end{tabular}

Table 2.0 : Employment and Fatalities on the Thai-Burma Railway (Source : Beattie, 2015; Kratoska, 2005)

This workforce laboured in monsoon conditions without; adequate accommodation, food, clothing, medicine or footwear (Kinvig, 1992). Indeed, in the absence of appropriate medicines and medical care, diseases such as; malaria, beri-beri, tropical ulcers, dysentery, cholera, general toxaemia and pellagra, along with the cruelty and violence administered by the Japanese and Korean guards all contributed to high fatality rates that characterised the construction phase (Kinvig, 1992). The imprecise nature of figures for Asian labourers (sometimes referred to as 'Romusha'), are complicated by the fact that the Japanese captors whilst recording fatalities of allied prisoners failed to do so in the case of the Asian labourers. Furthermore, in the case of the recruitment and forced conscription of Burmese nationals, the levels of desertion were considerable and a significant unknown number are thought to have perished in the harsh environment of the Thai-Burma border. This tragic summary of the cost of this construction constitutes a major reason for visiting Kanchanaburi. However, the interpretation and content of this tragic history receives mixed treatment at a variety of sites across the city. 
The city comprises a number of attractions associated with this period of its history and these provide one of the primary reasons for visitation. All of the sites associated with this period of the destinations ' tragic hlstory were visited and operators contacted to request interviews as part of the fieldwork (see full listing below).

\begin{tabular}{|c|c|c|c|}
\hline Title of Attraction & Operator & $\begin{array}{l}\text { Paid / Non Paid } \\
\text { Admission }\end{array}$ & Location \\
\hline $\begin{array}{l}\text { Thailand-Burma Railway } \\
\text { Centre }\end{array}$ & TBRC Co Ltd & Paid Admission & City \\
\hline The JEATH War Museum & $\begin{array}{l}\text { Wat Chaichumpol } \\
\text { Temple, Kanchanaburi }\end{array}$ & Paid Admission & City \\
\hline $\begin{array}{l}\text { Arts Gallery and War } \\
\text { Museum }\end{array}$ & Private Company & Paid Admission & City \\
\hline $\begin{array}{l}\text { Kancahanaburi War } \\
\text { Cemetery }\end{array}$ & $\begin{array}{l}\text { Commonwealth War } \\
\text { Graves Commission }\end{array}$ & Free Admission & City \\
\hline Chungkai War Cemetery & $\begin{array}{l}\text { Commonwealth War } \\
\text { Graves Commission }\end{array}$ & Free Admission & $5 \mathrm{Km}$ West of City \\
\hline $\begin{array}{l}\text { Hellfire Pass Memorial } \\
\text { Burma-Thailand railway }\end{array}$ & $\begin{array}{l}\text { Australian War Graves } \\
\text { Commission }\end{array}$ & Free Admission & $\begin{array}{l}70 \mathrm{Km} \text { North West } \\
\text { of the City }\end{array}$ \\
\hline
\end{tabular}

Table 3.0 : Kanchaburi Visitor Attractions and Sites associated with the Second World War and considered as part of the fieldwork associated with this paper. 
The key sites include: the 'Bridge over the River Kwai', a non-paid admission, metal railway bridge to the north west of the centre of town which is still operational and serves as a major attraction for international tourists. Its fame is linked primarily to filmic heritage and specifically a Hollywood narrative from; 'the Bridge on the River Kwai' directed in 1957 by David Lean. This film achieved no less than seven academy awards, despite its limited historical and geographical legitimacy. It catalysed the 'Bridge on the River Kwai' mythology which as its narrative grew became more acceptable and simpler to access than historical record. The current bridge, located in Kanchanaburi constitutes a re-representation of heritage. The Thai-Burma Railway was composed of many bridges, developed by forced labour (Allied prisoners and Asian Labourers) across the length of the route from Bang Pong (Thailand) to Thanbyuzayat (Burma). The Thai-Burma railway traversed some 416 kms across rugged relief that required frequent bridges and cuttings. The bridge which so many tourists and visitors flock to, in the city of Kanchanaburi, is neither authentic nor historically pivotal. Like the river its identity has been changed to provide a past that can be more easily commodified and exploited. As Beattie $(2015,7)$ pointedly summarised:

"There was no bridge over the River Kwai. In fact there was no River Kwai."

The Thai authorities to satisfy visitor demand, changed the name of the river from Maeklaung to Kwai and the Thai-Burma railway never crossed the Khwae Noi tributary, that later achieved erroneous attention as the River Kwai. In reality, much farther north, near the Thai-Burma border the same railway crossed a tributary of the Khwae Noi; the Song Khalia River. It was in the British POW camp at the Song Khalia crossing that some of the worst excesses of the forced construction period occurred. It is probable, that this site inspired the initial 1954 book by Pierre Boule, that in turn catalysed the film (see Boulle, 1954). However, this camp was but one of approximately 55 that are recoded on the length of the route (Australian-Thai Chamber of Commerce, 2011). This route comprised numerous bridges and many POW camps. However, the filmic record has 
undoubtedly influenced the appeal of the destination, the development of its attractions and activities, constructing and re-representing destinations and sites (McCannell, 1976). Beeton (2016) in her appraisal of Film-induced tourism (2016) cites case after case, where impacts of representation in all forms of filmic and televisual media are shown to positively impact on visitation and destination awareness.

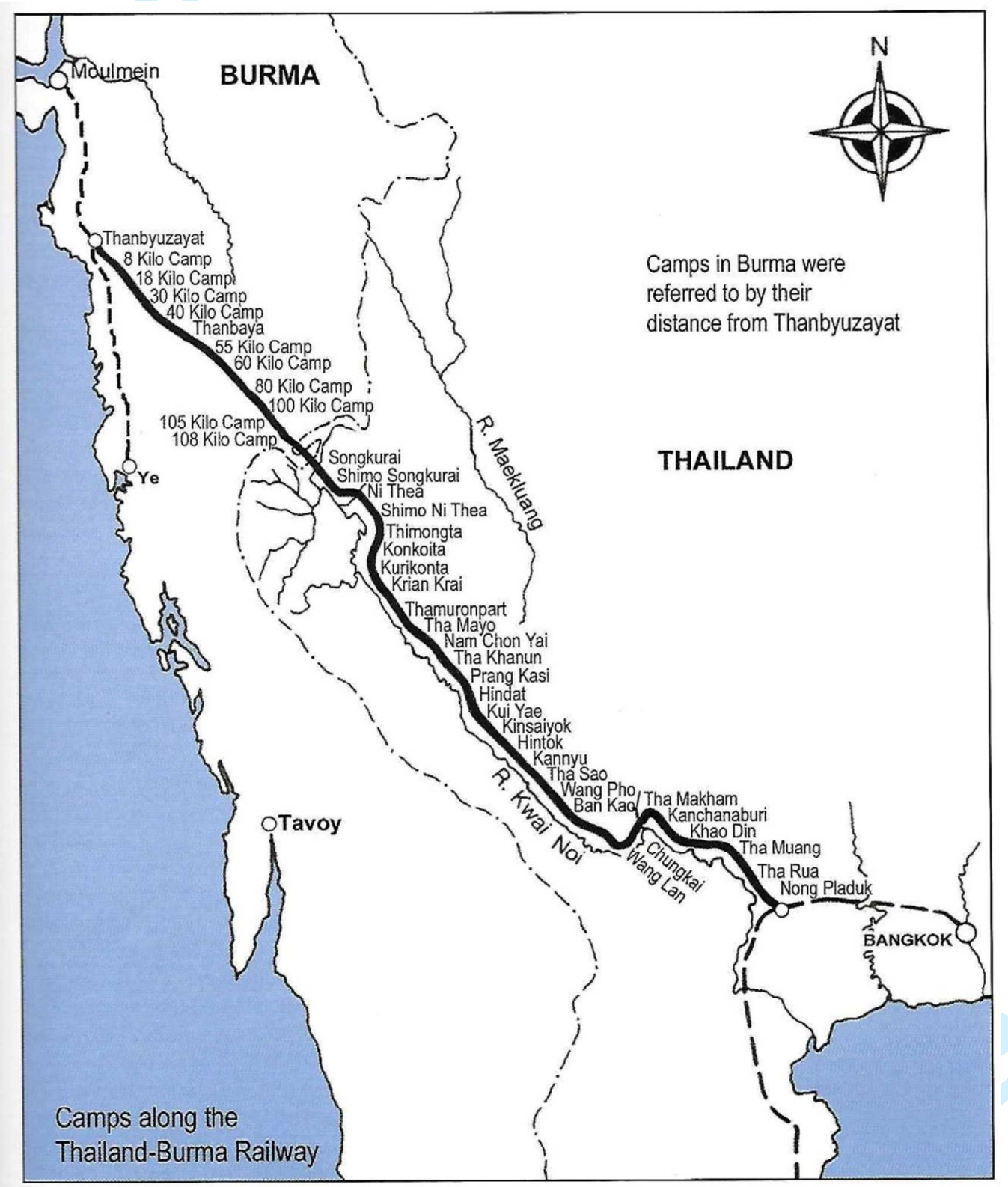

Diagram 2.0 : Location of POW and Forced Labour Camps on Thai-Burma Railway 1942-43 (Source:

Australian- Thailand Chamber of Commerce, 2011) 
The bridge at Kanchanaburi whilst originally built by the Asian labourers and Allied prisoners of war, traversed the River Maeklaung (renamed Kwai) and constitutes a further misrepresentation of the 'past'. The bridge is of steel construction rather than the wooden trestle bridge featured in the Bridge on the River Kwai (1957) film. Such wooden trestle bridges were the dominant construction type utilised on the Thai-Burma railway although as Beaumont (2009) noted many were demolished or lost following the cessation of World War Two hostilities.

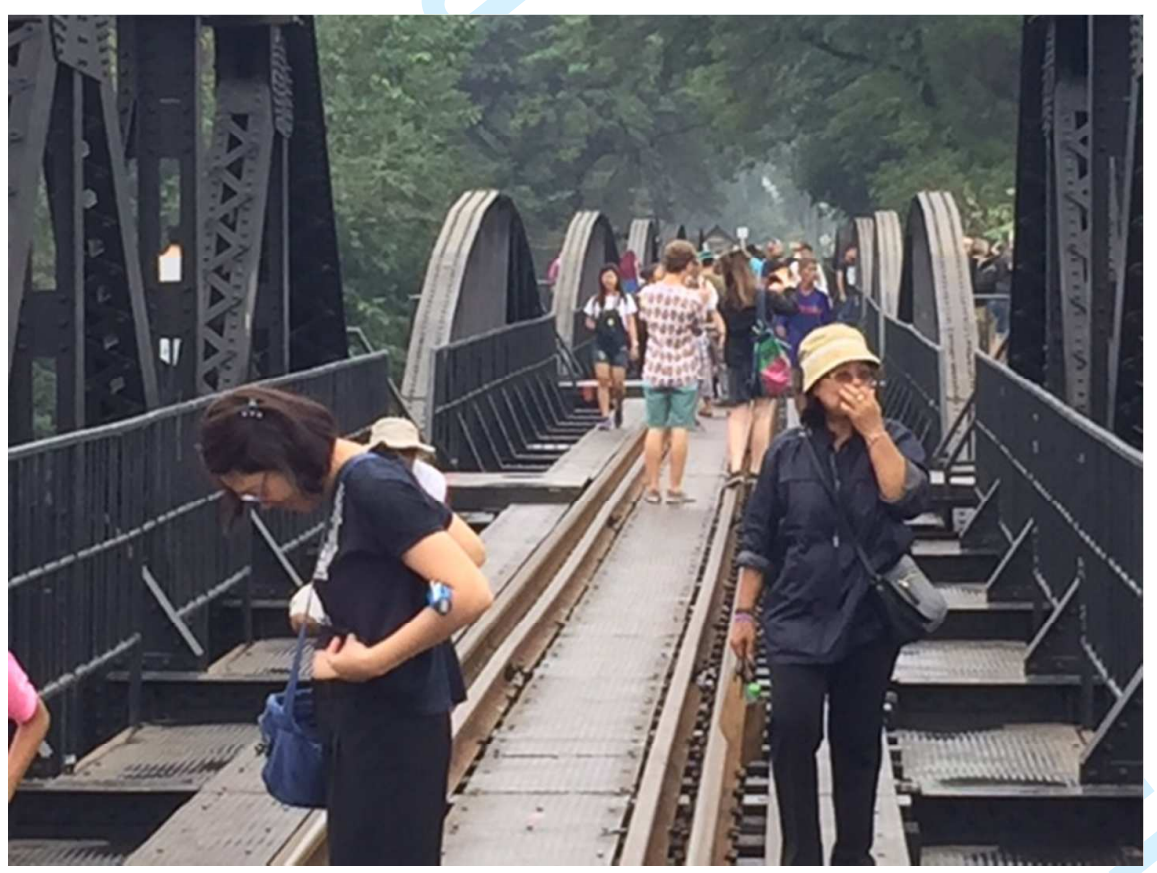

Photograph 1.0 : Tourists visiting 'Bridge on the River Kwai', Kanchanaburi, Thailand (Source J J

Lennon ).

The impact of this augmented historical reality was catalysed by the filmic narrative of the Bridge of the River Kwai . This clearly has parallels in other destinations with a dark history. In 1981, a generation were reintroduced to the genocide of the Khmer Rouge, through the Roland Jaffe film; 
the Killing Fields. This filmic narrative provided a link to a true story and an abridged consideration of the complex cause of this barbaric regime's rise to power. The Killing Fields film, has an eponymously titled tourist attraction in the Cambodian capital; Phnom Penh. Whilst this constitutes a significant and well visited site, (second only in visitor numbers to the Khmer temple complex of Angkor Wat), it fails to effectively or accurately educate visitors about the scale of this genocide. For example, the single Killing Field attraction in Phnom Penh fails to highlight that almost 350 such sites existed across Cambodia during the murderous period of Khmer Rouge control in Cambodia (1975-9). Furthermore, the later loss of such heritage and historical evidence since 1979 is a further omission, appropriately tragic in its own context. Despite these facts visitation continues to grow as Riley et al noted:

"...locations need not be beautiful nor the storylines positive in order to attract visitors" (Op cit, 932).

Indeed, the pursuit of historical accuracy has rarely been the motivation of visitors. As Seaton and Hay (1989) recorded in their analysis of the impact of the impact of the film Braveheart on Scottish Tourism. Visitors were motivated to visit Scotland to experience and visit locations featured in the film, even though much of it had been filmed in Ireland, because of a more accommodating national tax regime. Interestingly, the same tourists would often then continue on to or revisit Ireland, to experience the 'faux' heritage sites which were the in fact 'authentic' film locations.

In the case of Kanchanaburi, the bridge is now a major attraction in the heart of the city where tourists of all nationalities visit and cross, in a seemingly endless stream of guided and independent tours. According to Beaumont (2012), this particular site offers for some: 
“... displaced significance- that is a site that lacks heritage authenticity being invested with an emotional power at the level of individual memory or popular culture..."(Op cit 23)

However, this bridge is distant from historical fact and geographical location. Indeed, like some of the related attractions in the city, historical accuracy has been lost as war time heritage is exploited and loosely interpreted or ignored. This leads at best to dilution and at worst to inaccuracy. The represented history of the Thai-Burma railway has also been at least partially oriented towards a narrative of Allied loss. Indeed, in the majority of the attractions in Kanchanaburi, the Asian loss is minimised and the 'appropriation' of the narrative is evident. In the case of the JEATH museum ( the name is an abbreviation of; Japan, England, America, Australia, Thailand and Holland), the orientation towards an Allied narrative is apparent. The museum structure is a replica POW hut and the interpretation though amateurish is focussed around the conditions, work regime, diet, disease and sickness the allied prisoners experienced. The much larger Asian sacrifice remains undocumented at this location. Interestingly, this museum was established in 1977 by the chief abbot of the Wat Chaichumpol, in Muang, near Kanchanaburi. The content and interpretation of the museum is interestingly selective. For example, the introductory orientation makes claims which are hard to substantiate and difficult to comprehend (see below).

"The word JEATH also replaces the word Death because it sounds too horrific. The JEATH museum is a very important part of the history of Death Railway which will complete your visit to the River Kwae Bridge (sic)." (JEATH War Museum, 2016, 5)

Such content is confused and partial, abbreviated and problematic.

The Art Gallery and War Museum in Kanchanaburi, presents an even more problematic approach to this period. Herein , the 'Bridge on the River Kwai' narrative and a disjointed look at key historical figures of World War Two is combined with; a Miss Thailand fashion museum, an ore and jewellery set of displays along with a range of defunct and rusting helicopters and small passenger aircraft. 
The museum is constructed in the style of a Chinese temple and contains a large variety of unconnected artefacts, covered in dust and obscured behind glass in dimly lit rooms. It comprises some authentic World War Two artefacts which include decaying photos and sketches, poorly constructed life size tableaux of prisoners of war, and a range of almost comedic truisms such as the; 'interpretive' notice illustrated below:

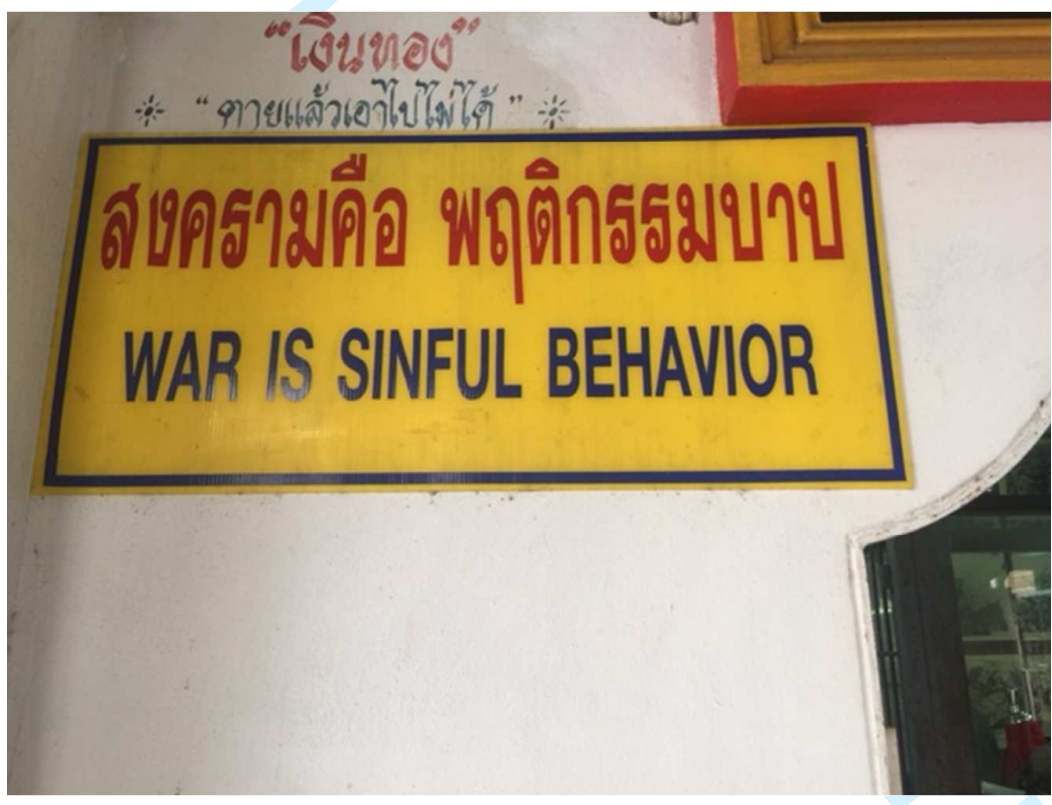

Photograph 2.0 : Typical Interpretation; Arts Gallery and War Museum, Kanchanaburi (Source: J J Lennon)

This is a private museum that venerates the original Chinese developer and his family in a shrine like space on the upper level. The largely erroneous historical narrative of the 'Bridge on the River Kwai', incorrect casualty figures and hyperbolic narrative characterise this site. In the worst excess, the museum also displays, in a glass case, the remains of a number of prisoners of war with the following interpretation; 
"In this glass monument, the remains of 104 of the prisoners who worked as labourers during World War Two are kept on the second level and the remains of another two are kept on the third level, making a total of 106" (see below)

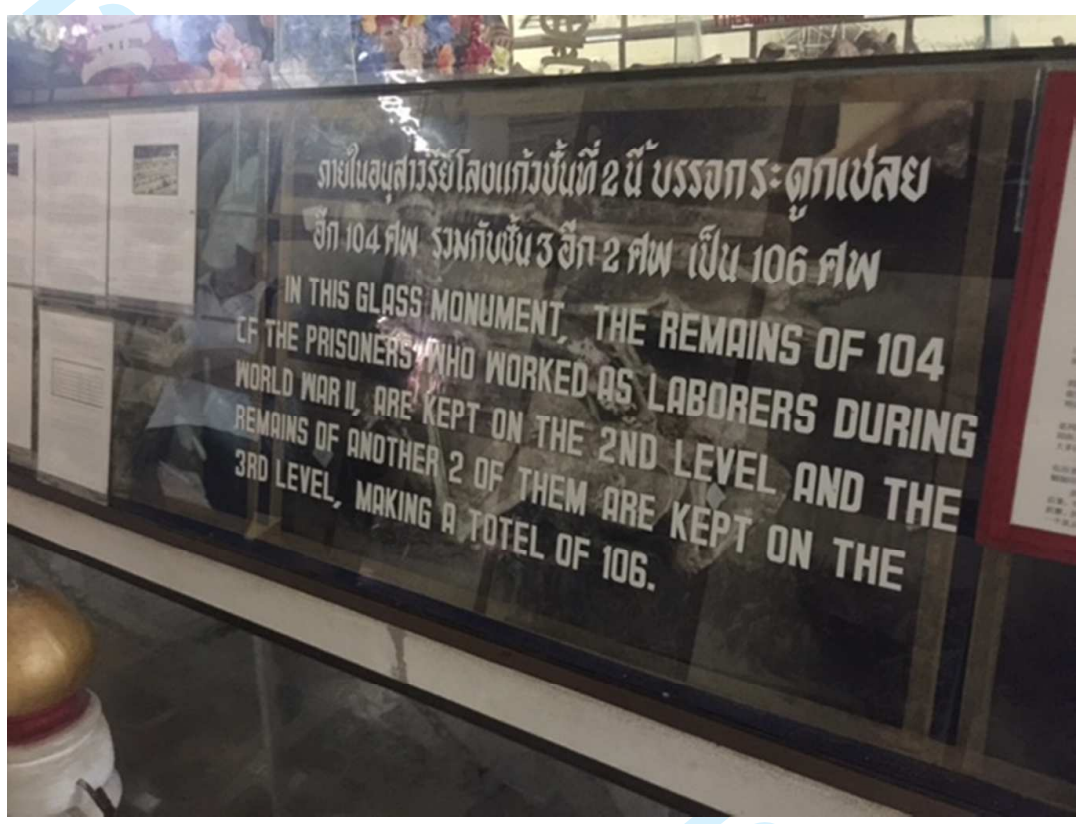

Photograph 3.0 : Display of Human Remains: Arts Gallery and War Museum, Kanchanaburi (Source : J J Lennon)

This gratuitous display is accompanied by minimal interpretation or context and provides little more than shock value. The quality of conservation in this museum is limited and evidence of vermin infestation and loss of artefacts are apparent throughout. Beaumont (2012) suggested that these are Romusha remains but the museum data is far from precise. The only certainty is that this is a facility which profits from artefacts of conflict and human loss.

In contrast, two related attractions do seek to relate a more authentic and historically defensible approach to the Thai-Burma railway. They are; the Hellfire Pass Memorial, Burma-Thai Railway http://hellfire-pass.commemoration.gov.au/ and the Thailand-Burma Railway Centre 
https://www.tbrconline.com/. The latter opened in 2003, and is a visitor, research and documentation centre. It is located within Kanchanaburi, and its development is very much the life work of one individual; Ron Beattie, an ex-Australian army, civil engineer who has passionately researched the Burma-Thai Railway since the early 1990s. He has spent many years researching the location and construction of the railway, and has lobbied for conservation and quality interpretation over the same period. Following assistance from the Netherlands government, the Thailand-Burma Railway Centre is now the major repository for artefacts and documentary evidence of the development and human cost of the railway. It provides a research and information service for those interested in tracing former prisoners of war and those involved in the construction. The interpretive content is deliberately non-partisan and based on donated and collected evidence, and a balanced narrative which provides clarification of the full extent of the cost of construction in terms of Allied and Asian lives. This site also highlights the positive role of some Thai nationals in relation to the Prisoners during the Second World War. The exhibition highlights the interventions of; Mr K Gardiner (Siam Architects Imports Co), Mr E Heath (Borneo Co), Mr R Hempson (Anglo-Siam Corporation), Nai Boonpong Sirivejjabhandu and Nai Lee Soon, who were all associated with the ' $V$ ' corporation; who were a network of those opposed to the excesses of the Japanese 'occupation' of Thailand They were responsible for passing money and medicines to POWs. Whilst undoubtedly heroic and important, it is a small part of the narrative that perhaps serves a wider more politically pragmatic purpose and portrays a degree of resistance to the Japanese which of course is a more attractive perspective on this period of Thai history.

Hellfire Pass Memorial, Burma-Thai Railway is the other notable heritage site that deals with the tragic past of this place in a non-exploitative and sensitive manner. However, its construction was not without controversy and the contested nature of the multiple narratives of this place and how they changed since the initial consideration of the site in the 1980s have been documented at length by Beaumont (2012). This analysis probes how the range of nationalities were represented and charts the range of agendas and interest groups involved in the complex interplay of remembrance 
of captivity and conflict. This site is located $80 \mathrm{~km}$ north west of Kanchanaburi on land owned by the National Security Command (the Thai Army). This location is historically since it saw some of the worst excesses of the Japanese captors. However, this is also an important relationship between tenant and land owner, and constitutes an 'enclave' of quality heritage interpretation that remains dependent upon the Thai government's understanding and respect. As the site leaflet introduction to the memorial intimates:

“The Memorial provides an important educational function for the people of Thailand and visitors from Australia and other countries. The memorial stands as an enduring symbol of the close relationship between Thailand, Australia and those nations whose citizens worked on the BurmaThailand railway." (Australian Government, 2016, 4)

The site is synonymous with the section of the rail route between Konyu and Hintok, which saw a major concentration of work on the railway construction between 1942-43 involving approximately 2,000 Australian and British prisoners (Australian Government, 2016). At this site, the excavation of soil and rock was infamously carried out with limited machinery and predominantly by hand. Prisoners mainly used; hammers, drills, picks and shovels to remove rock. As production timescales became critical to Japanese engineers and productivity was increased at great human cost ( Hearder, 2009). Shifts were extended from 12 to 18 hours, with the workplace lit by wood fires and oil pot lamps. This gave the impression of fires in a hell like location hence the application of the title 'Hellfire Pass' by the Prisoners (Australian-Thai Chamber of Commerce, 2011). In 1995, the Australian Government provided A\$ 1.6 million (Austrian Dollars) for the development of a substantial memorial centre and related visitor infrastructure at this location to commemorate the events of the Railway construction and the human cost. The interpretation of this site makes strong use of the audio testimony of Prisoners of War in a self-guided tour. The visitor centre element incorporated illustrated and narrative based panels within the Memorial. It is deliberately not built 
around artefacts and has a clear focus on remembrance and learning, that provides due weighting to the extent of Asian as well as Allied losses.

\section{Memory, memorial and re-representation; Hell fire Pass and beyond}

Memory remains contested and selective in many aspects of the World War Two heritage displayed in the city and environs of Kanchanaburi. The context of incarceration, forced labour, atrocity is overlaid with competing memories of differing national groups. However, this city offers a range of contrasting narratives for visitors and tourists, who may have limited understanding of the competing sensitivities and agendas present. This workforce laboured mercilessly in monsoon conditions without adequate accommodation, food, clothing, medicine, clothing or footwear (Kinvig, 1992).In the absence of appropriate medicines and medical care, diseases such as; malaria, beri-beri, tropical ulcers, dysentery, cholera, general toxaemia and pellagra took their toll. This along with the cruelty and violence administered by the Japanese and Korean guards all contributed to the high fatality rates that characterised the construction phase (Kinvig, 1992). Beaumont (2012) asserts that the site of Hellfire Pass is:

“...vulnerable to charges of selective and nationalistic representation and is inherently dissonant with local memories and cultural practices. Hence the sustainability of such heritage is fragile, dependent upon diplomatic negotiation and a continuing perception on the part of the host country that the heritage development is to its economic and political benefit." (op cit, 21) 
The potential for the controversy in relation to content and interpretation within this site was considerable. Indeed, the potential impact on diplomatic and economic relations between Thailand and Japan was a concern during the site evolution still and remains contentious as the Australian government wishes to make further investment in the site form 2017 onwards (Lennon 2017). The site and content also risks drawing attention to the Thai co-operation with the Japanese during World War Two; a period that receives limited coverage in other Thai museums. The co-operation agreement of 1942 between Japan and Thailand and the reality of Japanese occupation sits uncomfortably with narratives of nationalism and self-reliance (Blackburn, 2010). The distant Thai past of empire and conquest, presents a more acceptable history for the purpose of nationhood. However, this selective interpretation of the past has also to be seen against a fairly mercenary approach to commercialising elements of the past. In the case of Kanchanaburi, this is illustrated each year with a son et lumiere performance that relates the 'history' of the 'Bridge on the River Kwai'. This visitor entertainment focuses on the allied bombing of the 'bridge' in 1944-45, and the civilian loss recorded. This lights and firework show attracts thousands to the event generating significant economic impact at a local level. This spectacle plus the commercial exploitation of the 'River Kwai' narrative from T-shirt and souvenirs to resorts utilising the River Kwai as a destination marker, evidence how rapidly an acceptable and increasingly distant, interpretation of the past can be capitalised upon. 


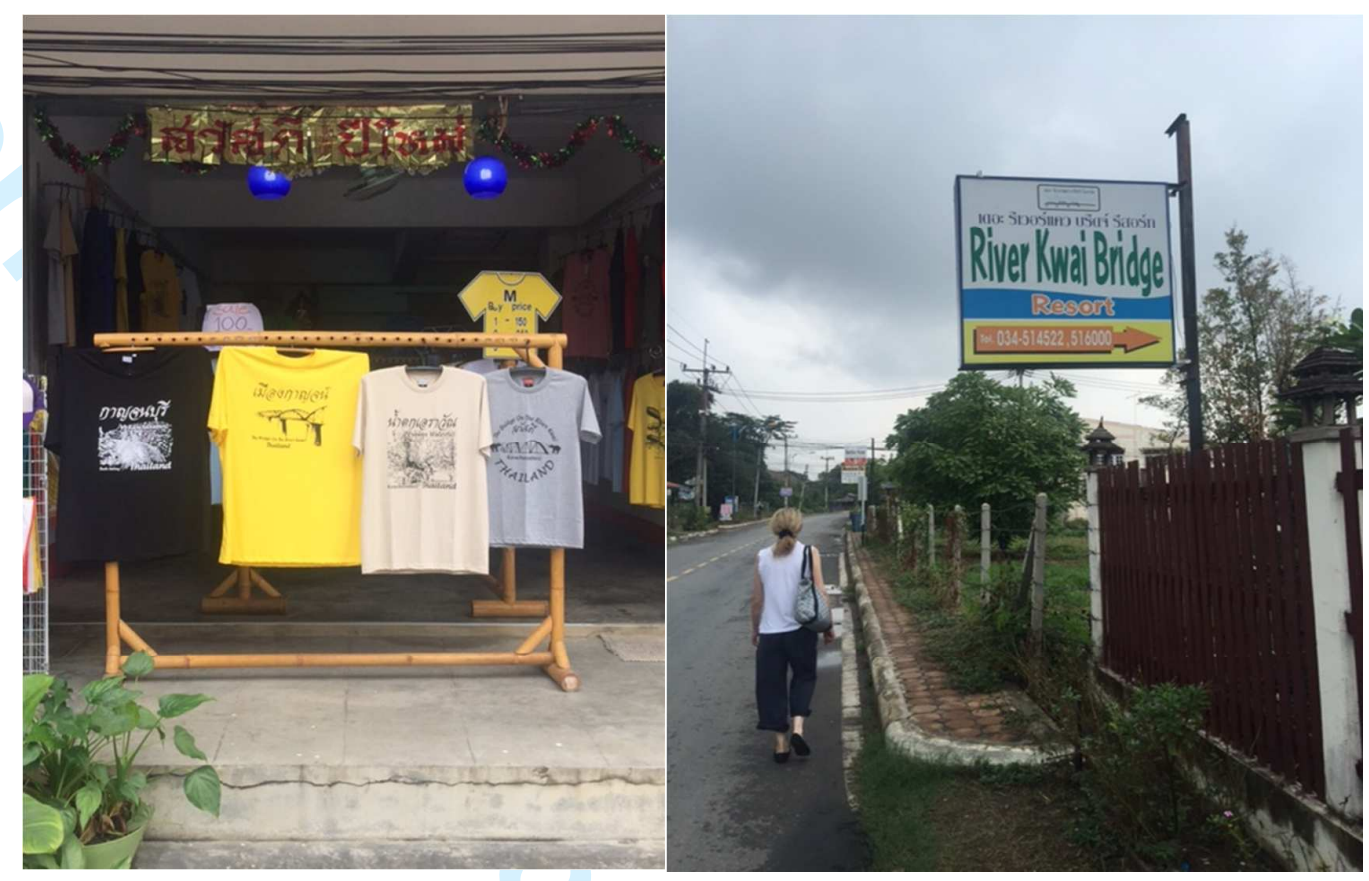

Photograph 4.0: River Kwai Bridge T-Shirt Merchandise and Resort Names, Kanchanaburi (Source:

\section{J J Lennon)}

Kanchanaburi is defined by misinformation, diluted history and the selective appraisal of the past. Its primary attractions are located within a context of heritage that is neither neutral nor accurate. It is contingent on the political and cultural context of the location; Thailand. Heritage, in this respect is constructed, represented and re-represented to assert the primacy of national and political identity. The tragic narrative is at one level appropriated by some of those with access to tangible heritage, memories and artefacts. In the most poignant of all of the sites of Kanchanaburi; the main World War Two graveyards, the visitor is overawed by the scale of the loss. Yet, this belies the unmarked and unrecorded loss of the so-called Romusha. The table below records burials and estimated deaths at Chungkai and Kanchanaburi cemeteries in Thailand and Thanbyuzayat in Myanamar. 


\begin{tabular}{|c|c|c|c|c|c|}
\hline Nationality & $\begin{array}{l}\text { POW / } \\
\text { Labourers }\end{array}$ & $\begin{array}{l}\text { Chungkai } \\
\text { Cemetery }\end{array}$ & $\begin{array}{l}\text { Kancahanaburi } \\
\text { Cemetery }\end{array}$ & Thanbyuzayat & TOTAL Deaths \\
\hline British & $30,000+$ & 1,384 & 3,568 & 1,588 & 6,540 \\
\hline Dutch & $18,000+$ & 313 & 1,896 & 622 & 2,831 \\
\hline Australian & $13,000+$ & - & 1.362 & 1,348 & 2,710 \\
\hline Malaysian & N/A & 37 & 104 & 79 & 220 \\
\hline Indian & $\mathrm{N} / \mathrm{A}$ & 6 & 12 & 15 & 33 \\
\hline Unknown & - & - & 35 & 114 & 149 \\
\hline American & $700+$ & & $\begin{array}{l}\text { Remains } \\
\text { Repatriated }\end{array}$ & $\begin{array}{l}\text { Remains } \\
\text { Repatriated }\end{array}$ & 133 \\
\hline Subtotal & 61,000 & 1,740 & 6,977 & 3,766 & $12,616+$ \\
\hline $\begin{array}{l}\text { Asian } \\
\text { Labourers }\end{array}$ & $200,000+$ & & & & $80,000+$ \\
\hline Japanese & 15,000 & & & & 1,000 \\
\hline TOTAL & 275,000 & & & & $94,000+$ \\
\hline
\end{tabular}

Table 4.0 : Burials, Recorded and Estimated Deaths on the Burma-Thai Railway (Source: AustralianThai Chamber of Commerce, 2011)

During World War Two the Japanese Forces recorded the deaths of allied prisoners and allowed burial and marking of graves. This record keeping and level of understanding was not extended to the Asian labourers. Whilst it is understandable that these are fundamentally Allied War Graves, this reaffirms that the remembrance of war is political and the celebration and development of heritage shapes and sustains narratives of political legitimacy and identities (Gegner and Ziino, 2012). The physical manifestation of war memorialization in areas such as cemeteries, uses distinct semiotic and aesthetic strategies to represent a sanctioned and acceptable interpretation of war. However, 
these are not simply the narratives of elite groups (cf Hall, 1992) but rather absorbing a multiplicity of war narratives. The narrative of the Asian Labourers whilst represented in Hellfire Pass and Thailand-Burma Railway Centre is not the dominant interpretation context from cemeteries to Hollywood. This is an interpretation of Allied loss, Allied struggle and ultimately an Allied victory. Heritage is contingent on the agencies that realise the narrative. This takes place in visitor centres and attractions and sustained with funding by governments or commercial endeavour. As Eyal (2004) concurs, memory is neither immutable or given, heritage is selectively interpreted, constructed and reconstructed, represented and re-represented to assert national, religious, personal and cultural identities.

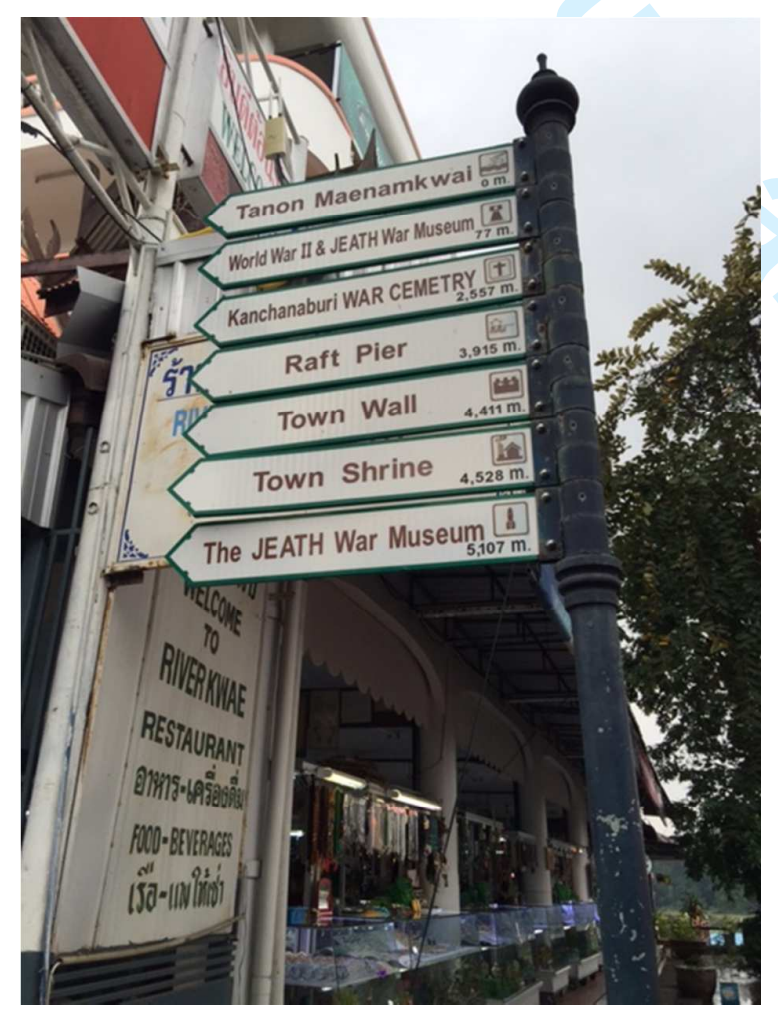

Photograph 5.0: Visitor Orientation, Kanchanaburi, Thailand (Source: J J Lennon) 


\section{Conclusions}

The city of Kanchanaburi is defined by a heritage that has changed over time. Many factors imbue the meanings and content of place. This is a function of a plethora of competing Influences and agendas; political, economic, cultural, demographic and historical. Ye this destination is defined by the Dark history of World War Two which is associated with this place. The critical mass of attractions focussed on the 'Bridge of the River Kwai' and the history of the construction of the Thai - Burma Railway provide the primary destination awareness and have been clearly harnessed in urban marketing and individual tourism product marketing whether accommodation, retail, attractions or events. The narrative of these products and this place remains problematic at a time when transparency of meaning and place has never been more apparent. The operators of visitor attractions, accommodation and other products that constitute for many visitors, the major learning experience (cf Lennon and Foley, 2000) have to be aware that there actions are about more than conservation and (mis) representation. The inaccuracy and exploitation of this tragic and dark narrative is easily exposed. Theses operators have potential to influence the historical, social and cultural meanings represented (Smith, 2006). The selection, interpretation and conservation of elements of the past of this place are critical in understanding what is considered and how it is represented (Ashworth, 2008).

The visitor attraction sites considered in Kanchanaburi provide multiple narratives around World War Two events. They offer a range of content driven by influences as diverse as simple commercial gain to the complex interaction of political, economic and ideological agendas (cf Gegner, 2012). In each case the interpretation is used to articulate heritage through objects, artefacts, audio recording, place or imagery. These elements exist in environment(s) of their creation; the World War Two heritage of Kanchanaburi is developed in a nation that has only a partial and selective acceptance of its role in this conflict. The visitor attractions examined in this research and their content have all reconstructed and re-represented the past. Historical memorialization remains 
embedded in interests that are global, commercial, ideological but rarely neutral. The interpretation of the Thai- Burma Railway and the narrative of the many victims associated with the construction merit respect, commemoration and consideration that is value free and not distorted by ideology or commercial imperatives. 


\section{References}

Ashworth G (2008) The memorialisation of Violence and Tragedy: Fuman trauma as Heritage in Graham B and Howard P (2008) (Eds) The Ashgate Research Companion to Heritage and Identity, (231-244) Ashgate, Farnham

Ashworth, G. (1996). Holocaust tourism and Jewish culture: The lessons of Krakow- Kazimierz. In M. Robinson, N. Evans, and P. Callaghan (Eds.). (1996). Tourism and culture- Towards the 21st century. Athenaeum Press, London

Australian Government (2015) Hellfire Pass Memorial Burma-Thailand Railway, Department of Veterans' Affairs, Office of Australian War Graves

Australian-Thai Chamber of Commerce (2011) HellFire Pass Memorial Thailand-Burma Railway, Australian Thai Chamber of Commerce

Beattie R (2015) The Death Railway, TBRC Co, Kanchanaburi, Thailand

Beaumont J (2012) Hellfire Pass Memorial Museum , Thai-Burma Railway Museum, (pp19-41) in

Beaumont J (2009) Contested Transnational Heritage: the demolition of Changi Prison in International Journal of Heritage Studies 15(4) (294-316)

Beaumont J (2005) Prisoners of War in Australian National Memory (184-194) in Moore B and

Beeton S (2016) Film-induced Tourism ( $2^{\text {nd }}$ Edition), Channel View Publications, Bristol

Botterill, D., and Jones, T. (2010). Tourism and crime. Oxford, UK: Goodfellow Publishing.

Dann, G., \& Seaton, A. (Eds.) Slavery contested heritage and thanatourism. Binghamton, NY: Haworth Hospitality Press.

Eyal G (2004) Identity and Trauma: Two forms of the will to memory in History and Memory, 16 (1) $(5-36)$

Hately Broad B (2005) (Eds) Prisoners of War; Prisoners of Peace Captivity, Homecoming and Memory in World War Two, Berg, Oxford

Blackburn K (2010) War Memory and Nation Building in South East Asia in South East Asia Research, $18(1),(5-31)$

Boulle P (2007) The Bridge over the River Kwai, Presidio Press Random House, New York

Gegner M and Ziino B (Eds) (2012) The Heritage of War, Routledge, London

Beeton S (Ed) (2016) Film-induced Tourism, Channel View Publications, Bristol 
Gegner M (2012) War monuments in East and West Berlin: Cold War symbols or different forms of memorial in Gegner M and Ziino B (2012) The Heritage of War, (64-87) Routledge, London

Gegner M and Ziino B (2012) The Heritage of War, Routledge, London

Hall S (1992) Encoding, Decoding in S Hall, D Hobson A Lowe and P Willis (Eds) Culture, Media, Language, (128-138) London, Routledge

Hardie R (1983) The Burma-Siam Railway, Imperial War Museum, London

JEATH War Museum (2016) The JEATH War Museum, Kanchanaburi, Thailand, Kanchanaburi, Thailand

Kinvig C (1992) River Kwai Railway, Bressey's, London

Kratoska W (2005) Labour in the Malay Peninsula and Singapore under Japanese occupation in Kratoska P H (Ed) (2005) Asian Labour in the Wartime Japanese Empire; Unknown Histories, New York, East Gate Books

Lennon J. J. (2010). Dark tourism and sites of crime. In D. Botterill \& T. Jones (Eds.), Tourism and crime. Oxford, UK: Goodfellow Publishers.

Lennon J (2009) Tragedy and Heritage in Peril : The Case of Cambodia in Tourism Recreational Research (Vol 3 No 2 pp 116-123)

Lennon, J.J. and Foley, M. (2000) Dark Tourism - the Attraction of Death and Disaster, Continuum. (now in $4^{\text {th }}$ International Edition)

Lennon, J.J and Foley, M (1996) 'Editorial: Heart of Darkness' in the International Journal of Heritage Studies 2 (1) 195-197.

Lennon J, and Smith H (2004) A Tale of Two Camps: Contrasting Approaches to Interpretation and Commemoration in the Sites at Terezin and Lety, Czech Republic in Tourism Recreation Research Vol.29 No.1 pp 15-25

Lennon J and Wight C (2007) Selective Interpretation and Eclectic Human Heritage in Lithuania in Tourism Management Vol 28 00519-529

Lowenthal D (1997) The Heritage Crusade and the Spoils of History, Cambridge University Press, Cambridge

McCannell D (1978) The Tourist: A new theory of the Leisure Class, Shocken Books, New York 
Mitchell, M. (Ed.). (2007). Remember me constructing immortality-Beliefs on immortality, life and death. New York: Routledge.

Philpott, C. (2016.) Relics of the Reich. York, UK: Trinners.

Riley R Baker D and Van Doren C (1998) Movie induced tourism in Annals of Tourism Research 25(4) (919-935)

Seaton, A. V. (1996). Guided by the dark; from thanatopsis to thanatourism. International Journal of Heritage Studies 2(4): 234-244.

Seaton, A. V., and Lennon, J. J. (2004). Moral panics, ulterior motives and ulterior desires: Thanatourism in the 21st century. In T. Singh (Ed.), New horizons in tourism: Strange experiences and stranger practices (pp. 63-82). Wallingford, UK: CABI Publishing.

Seaton A V and Hay B (1998) The marketing of Scotland as a tourism destination in MacLelland R and Smith R (1998) Tourism in Scotland, (209-239), International Thompson Press, London

Sharpley, R., and Stone, P. (Eds.). (2009). The darker side of travel. London: Routledge.

Skinner, J. (2012). Writing the dark side of travel. London: Berghahn Books

Smith L (2006) Uses of Heritage. Routledge, London

Thompson J (2002) The Imperial War Museum Book of the War in Burma 1942-1945, Macmillan, London

Tourism Authority Thailand (2016) Thailand reaps top global awards for three most popular tourist destinations in $2015 \mathrm{http}: / /$ www.tatnews.org/thailand-reaps-top-global-awards-for-three-mostpopular-tourist-destinations-in-2015/

Tunbridge, J. E., and Ashworth, G. J. (1995). Dissonant heritage: The management of the past as a resource in conflict. Chichester, UK: John Wiley

UNWTO (2016) Tourism Highlights 2016 Edition

White, L., and Frew, E. (2012). Dark tourism and place identity: Managing and interpreting dark places. Oxford, UK: Routledge. 
Case Study: Kanchanaburi and the Thai-Burma Railway - disputed narratives in the interpretation of War

\section{Abstract}

This paper considers the history and dark tourism attractions associated with a qualitative case study of the Thai-Burma Railway in the city of Kanchanaburi, Thailand. The paper considers how history has been abridged and distorted at a number of attraction sites in order to exploit the dark tourism commercial potential. The role of film media is considered as a critical element of the site narrative and the reality of the tragic past of this place is discussed within the context of Thailand's role in World War Two. The paper contains an analysis of all of the relevant attractions in the city and incorporates interview analysis with a range of operators and owners of such attractions. The results provide an original contribution to tourism knowledge in this field. Heritage is central to many urban destinations marketing strategy (Page and Hall, 2002) however, Kanchanaburi, through the urban attractions that constitute key motivations for visitation, utilises its dark history for commercial and ideological purposes. Where accurate World War Two interpretation was identified, it was maintained by balancing the requirements of national governments and institutions with acceptable levels of ambiguity and non-controversial perspectives on this urban location's dark past. This is the first time the heritage of this city has been considered in the context of urban destination marketing and the role of Thailand in World War Two. It provides an illustrative perspective on the enduring legacy of iconic film narrative and its role in understanding the dark past. 


\section{Introduction, Aims and Context}

The city of Kanchanaburi, located in the province of the same name in north east Thailand on the border with Myanmar is not a first stop destination for inbound tourists to Thailand. Indeed, Thailand offers the international visitor many alternative attractions, activities and contrasting experiences. Thailand welcomed more than29.9 million international visitors in 2015 and achieving an enviable 6th place in the world in terms of tourism expenditure. Performance of the nation across the years 2012-16 is detailed below.

\begin{tabular}{|l|l|l|l|l|l|}
\hline & 2012 & 2013 & 2014 & 2015 & 2016 \\
\hline Visitor Arrivals & & 26,547 & 24,810 & 29,881 & 32,611 \\
(m) & & & & & \\
\hline \% Growth & & & & & \\
\hline
\end{tabular}

Table 1.0: International Arrivals Thailand 2012-2015 (Source: UNWTO, 2016, Reuters 2017)

The primary pull factor remains the capital; Bangkok, with $21.9 \mathrm{~m}$ overnight visitors. This is followed by the beach locations of Phuket and Pattay City achieving $9.3 \mathrm{~m}$ and $8.1 \mathrm{~m}$ visitors respectively in 2015 (TAT, 2016). In contrast, Kanchanaburi, capital of Kanchanaburi Province, with a population of 31,327 , remains much less visited. The province is in the west of Thailand, $129 \mathrm{~km}$ from Bangkok, and covers a total area of approximately $19,483 \mathrm{~km}^{2}$ and is the country's third largest province.

In recent years, Kanchanaburi has seen some growth in short break tourism, predominantly by Thai nationals, travelling north from the urban sprawl of Bangkok, to the closest significant natural heritage destination. Kanchanaburi benefits from proximity to two major national parks in this part of Thailand:

- Erawan National Park (with its celebrated seven cascading waterfalls) 
- Sai Yok National Park (bordering Myanmar)

However, for some international tourists part of the attraction to this destination relates to the ThaiBurma Railway history and its representation in a range of sites in the city. The location has become synonymous with the railway and the 'bridge' over the River' Kwai' and a period of Second World War history made famous by filmic entertainment rather than historical narrative. It is now seen by some at least, as a destination associated with the dark heritage of World War Two. The aim of this paper is to illustrate the role of dark heritage in the visibility, marketing and content of this destination. For the first time the critical influence of iconic filmic narrative in the context of World War Two history of Thailand is explored and primary research on operators and owners of attraction sites is explored with reference to urban tourism to this destination.

\section{Dark Tourism and destinations associated with a tragic past}

Dark tourism (sometimes referred to as thanatourism) has become established since 1996 as a specialist area of tourism study. Death, suffering, visitation, and tourism have been interrelated for many centuries, but the phenomena was identified as such and categorized by Lennon and Foley in 1996 and was later the subject of the defining source text: Dark Tourism: The Attraction of Death and Disaster (Lennon and Foley, 2000).

The phenomenon exists across a range of destinations and demonstrates some elements of commonality in a variety of locations, indeed for useful discussion of the range of such dark sites and the potential for classification see; Stone and Sharpley, (2008) and Stone (2006). These dark tourism 
sites act as the meeting place for history and visitation where questions of authenticity and fact are sometimes juxtaposed with the operation of tourism facilities. What is celebrated, interpreted, and developed is often selective, and dilemmas of commemoration are reflected in the condition, nature, and content of these sites (for useful discussion in the context of the communist past sees Bailey, Amore and Hall 2017). The tourist attractions at such sites become key physical elements of heritage either authentic or created that combines in whole or part: commemoration, history, and record. Dark tourism attractions demonstrate a scale of contrasting demand from consumers for this type of experience. Strange and Kempa (2003) offer a valuable range of incarceration sites operating as visitor attractions that clearly have darker elements as part of the experience and appeal. However, they also constitute commemoration, historical reference, narrative legacies, and can constitute populist visitor experiences. These tourism sites in some cases become one of the few remaining commemorative elements of victims and their testimonies. In such cases the content and its narrative interpretation take on critically important values in understanding a shared dark past.

For many years, humans have been attracted to sites and events that are associated with death, disaster, suffering, violence, and killing. From ancient Rome and gladiatorial combat to attendance at public executions in London and other major cities of the world, death has held an appeal. Sites associated with death and disaster seems to exert a dark fascination for visitors and is frequently linked to crime locations and the perpetration of both lawful and unlawful acts (Lennon, 2010). The sheer diversity of forms of dark tourism sites is significant and has been the subject of research (see, e.g., Lennon and Foley, 1996, 2000; Seaton, 1996; Seaton and Lennon, 2004; Dann and Seaton, 2001; Ashworth, 1996; Sharpley and Stone 2009).

Further useful contributions to the area include issues of interpretation and selective commemoration (White and Frew, 2012), cross-disciplinary studies in the field of the sociology of death and death studies (Mitchell, 2007), literature and writing (Skinner, 2012), problematic heritage (Ashworth, 1996, Tunbridge and Ashworth, 1995), the area of criminology/crime sites (Botterill and 
Jones, 2010), the architectural legacy of dark sites (Philpott, 2016) and in development of scales of dark heritage (Sharpley and Stone 2009).

Tourism and death enjoy a curious relationship. Death and acts of mass killing are a major deterrent for the development of certain destinations, and yet such acts can become the primary purpose of visitation in others. In the literature that has emerged since identification and analysis of the phenomenon dark tourism sites have been identified as destination 'pull' factors, and the relationship between crime and its attraction to visitors has been explored ( Dalton 2015). The consideration to date has included:

- Visits to death sites and disaster scenes whether real or created (for useful discussion see Stone, 2006)

- Visits to sites of mass or individual death (see for example Beech 2009, Lennon and Foley 2000)

- Visits to sites of incarceration (Strange and Kempa, 2003)

- Visits to representations or simulations associated with death (Seaton and Lennon, 2004)

- Visits to re-enactments and human interpretations of death (Seaton and Lennon, 2004)

Murder, execution, and sites of lawful and unlawful deaths have served to attract the attention of visitors and residents from ancient times to the current day. The city of Kanchanaburi offers further evidence of the phenomenon. In this context and in other cases education and the nature of the learning experience are frequently used to justify and explain motivation for development and visitation in the modern world. Indeed, the idea of travel as an educational experience of new and previously unvisited destinations is frequently used as a rational argument associated with discussions of modernity. It is important here to consider the significance of film, television and communications technology that serves to heighten awareness of 'dark' destinations (Lennon 2009, Foley and Lennon, 1996) and destinations more generally (Seaton and Hay, 1998). 
The paper and the material contained below provide a useful addition to the literature and will bring a focus to this part of Thailand which has seen limited exploration in mainstream tourism literature. The paper provides a case study of a city; Kanchanaburi, that has become synonymous with heritage and filmic narrative that relates directly to the tourism experience of many visitors. This provides the foundation for exploring the role of Thailand and the use and treatment of prisoners of war and native labour by the Japanese army, a hitherto underexplored aspect of Thailand's dark heritage.

\section{Methodology}

The paper draws on literature, historical documents and tourism publications related to World War Two and the incarceration and forced labour associated with the Thai-Burma Railway and the city of Kanchanaburi. This part of Thailand has been identified given the significant focus on World War Two heritage and history associated with the city and the region. It presents the largest amount of heritage and related attraction development of any of the cities of Myanmar and Thailand connected by the route of the Thai-Burma Railway in 1942-43.

Qualitative fieldwork incorporating all related tourist attractions, monuments and commemorative sites was undertaken in Norther Thailand in January 2017. Curators, managers, operators and tourist authorities were contacted in advance of the fieldwork by email to request interviews. The sites identified are detailed below.

\begin{tabular}{|l|l|l|l|}
\hline Title of Attraction & Operator & $\begin{array}{l}\text { Site Review and } \\
\text { (Fieldwork Interview }\end{array}$ & Location \\
\hline
\end{tabular}




\begin{tabular}{|l|l|l|l|}
\hline & & Requests) & \\
\hline $\begin{array}{l}\text { Thailand-Burma Railway } \\
\text { Centre }\end{array}$ & TBRC Co Ltd & Yes (Yes) & City \\
\hline The JEATH War Museum & $\begin{array}{l}\text { Wat Chaichumpol } \\
\text { Temple, Kanchanaburi }\end{array}$ & Yes (Yes) & City \\
\hline $\begin{array}{l}\text { Arts Gallery and War } \\
\text { Museum }\end{array}$ & Private Company & Yes (Yes) & City \\
\hline $\begin{array}{l}\text { Kancahanaburi War } \\
\text { Cemetery }\end{array}$ & $\begin{array}{l}\text { Commonwealth War } \\
\text { Graves Commission }\end{array}$ & Yes (Yes) & City \\
\hline $\begin{array}{l}\text { Chungkai War Cemetery } \\
\text { Gommonwealth War } \\
\text { Graves Commission }\end{array}$ & Yes (Yes) & 5 Km West of City \\
\hline $\begin{array}{l}\text { Hellfire Pass Memorial } \\
\text { Burma-Thailand railway }\end{array}$ & $\begin{array}{l}\text { Australian War Graves } \\
\text { Commission }\end{array}$ & Yes (Yes) & $\begin{array}{l}70 \text { Km North West } \\
\text { of the City }\end{array}$ \\
\hline
\end{tabular}

Fieldwork Research Sites, Kanchanaburi and Region

The table above contains all of the primary sites visited by tourists and no related World War Two site in the area was excluded. In two sites, subjects were unwilling to participate however some nine individuals were interviewed from four of the identified sites (representing a sample of $67 \%$ of all sites). For those interviewed in relation to the subject area, a standard questionnaire based on a rolling data base, relevant to particular sites was utilised. Where permitted interviews were taped and transcribed. It should be noted that the subject area was seen as sufficiently sensitive by the majority of those contacted that audio recording was deemed unacceptable and anonymity was requested and preserved. The data below has been assembled to provide a perspective on what is both a historically problematic and ideologically conflicted use of the narrative of the part of the Second World War and its problematic exploitation. 


\section{Understanding the historical context}

This area of Thailand was an important part of the narrative of the Second World War and Japan's struggle for dominance in this part of Asia. The outbreak of hostilities in December 1941 with the simultaneous attacks on Pearl Harbour and British colonies saw the Japanese invasion of the Malayan peninsula with the goal of capturing Singapore. In February, 1942, the fall of Singapore saw the surrender and capture of an enormous number of allied prisoners. In total some; 28,500 British, 18,000 Australians, 67,000 Indians and 14,000 local volunteers surrendered to the Japanese. This significant volume of manpower was later to be deployed in the construction of the Thai - Burma railway sometimes referred to as the 'Death Railway'. Burma was an important invasion target for the Japanese since it provided a critical allied supply chain to their adversary China. However, Burma also offered access to raw materials for the Japanese war machine hence, some form of rail link between Thailand and Burma was considered a necessity.

It is important to note that during the Second World War, Thailand signed a co-operation agreement with the Japanese government in January 1942, declaring war on both America and Britain only days later. However, as the conflict in WW2 progressed, the co-operation agreement assumed many of the characteristics of an occupation (Thompson, 2002). At a national level there is significant sensitivity about this period of Thai history and as Beaumont $(2012,26)$ noted:

“...there has been something of a national amnesia about the Thai's bystander role as war crimes were committed on their territory."

This selective attention to the history of conflict and state actions is not unique to Thailand and characterises the way many governments and nations re-represent their past. For further discussion see Lowenthal (1997) and for a comparable example in the case of Lithuania, during the Second World War, see Lennon and Wight (2008). In the case of Thailand, the events of late 1942 were 
critical in understanding the extent of this process of re-representation of history. Japan ordered the development of a Thai- Burma railway in 1942-3, given Allied pressure on sea based supply chains. Japan had conquered much of South East Asia within six months of the Pearl Harbour attack on December 1941 (Beattie, 2015). However, the defeat of the Japanese Navy at the Battle of Midway in 1942 resulted in major supply chain problems for Japanese troops located in Burma and the importance of a potential rail link became highly significant. The railway construction of such a route was not feasible with heavy construction plant and machinery which was impossible to transport to the site given the terrain and climate (Thompson, 2002). Accordingly, the $415 \mathrm{~km}$ railway from Bampong (Thailand) to Thanbyuzayay ( Burma) was to be constructed by Asian 
labourers and Allied prisoners of war.

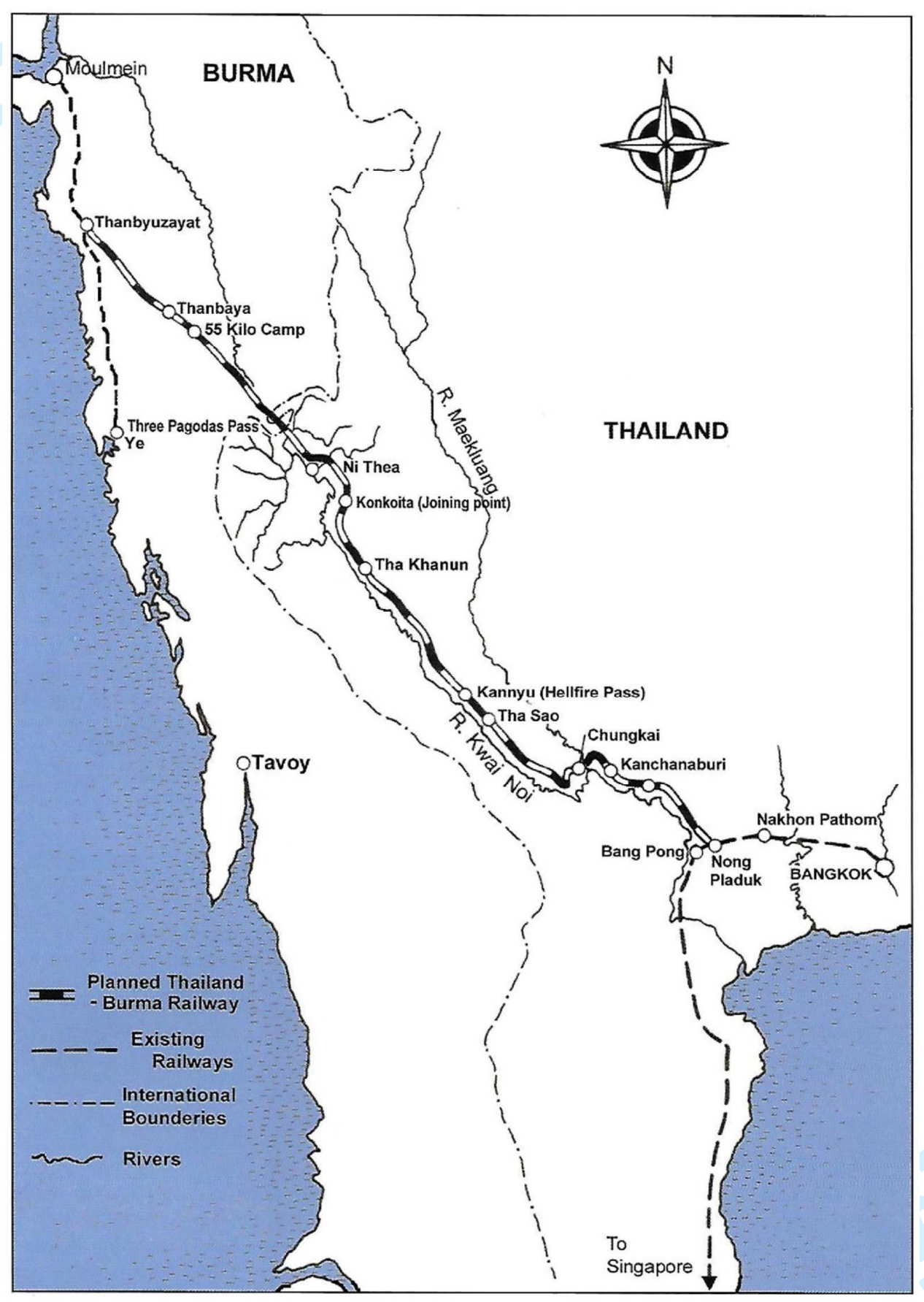

Diagram 1.0: Map of Route of Thai-Burma Railway 1942-43 (Source: Australian-Thailand Chamber of Commerce 2006) 
The large number of allied POWs and the indigenous populations of some of the Japanese occupied Asian nations provided the forced labour supply. The railway was to cross a range of rivers, coastal plains, foothills and inaccessible mountainous border regions. The latter terrain often required deep cuttings into solid rock, large embankments and numerous wooden trestle bridges (Kinvig, 1992). Much of this difficult construction work was undertaken by hand by POWs and Asian forced labour, using tap drills and explosives. Forest was cleared and earth was moved manually at significant human cost (Hardie, 1983). The use of prisoners of war in such dangerous tasks, assisting their captor's in the war effort, was directly in contravention with the Geneva Convention. However, as a non-signatory Japan choose to deploy large numbers of allied prisoners in this task. The prison workforce was extended significantly by the use of Asian labourers (predominantly Malays, Tamils and Burmese). In total across the duration of the construction the workforce consisted of circa 330,000 including some 61,000 Prisoners of War (Australian -Thai Chamber of Commerce, 2007) as detailed below.

\begin{tabular}{|l|l|l|}
\hline Nationality & Employed on Thai - Burma Railway & Deaths \\
\hline $\begin{array}{l}\text { People of Malayan } \\
\text { Origin (including } \\
\text { Malays, Tamils and } \\
\text { Chinese) }\end{array}$ & 75,000 & 42,000 \\
\hline Burmese & $\begin{array}{l}\text { Initial Japanese draft circa 175,000 } \\
\text { Following desertion } \\
90,000\end{array}$ & $\begin{array}{l}\text { 40,000 (does not include } \\
\text { deaths of those who } \\
\text { deserted) }\end{array}$ \\
\hline British & 30,131 & 6,648 \\
\hline Javanese & 7,500 & 2,900 \\
\hline Australian & 13,004 & 2,710 \\
\hline Dutch & 17,990 & 2,737 \\
\hline Chinese (Singapore) & 5,200 & 500 \\
\hline America & 686 & 132 \\
\hline Aminese & 200 & 25 \\
\hline TOTAL & $\mathbf{2 3 9 , 7 1 1}$ & $\mathbf{9 7 , 6 5 2}$ \\
\hline
\end{tabular}


Table 2.0: Employment and Fatalities on the Thai-Burma Railway (Source : Beattie, 2015; Kratoska, $\underline{2005)}$

This workforce laboured in monsoon conditions without; adequate accommodation, food, clothing, medicine or footwear (Kinvig, 1992). Indeed, in the absence of appropriate medicines and medical care, diseases such as; malaria, beri-beri, tropical ulcers, dysentery, cholera, general toxaemia and pellagra, along with the cruelty and violence administered by the Japanese and Korean guards all contributed to high fatality rates that characterised the construction phase (Kinvig, 1992). The imprecise nature of figures for Asian labourers (sometimes referred to as 'Romusha'), are complicated by the fact that the Japanese captors whilst recording fatalities of allied prisoners failed to do so in the case of the Asian labourers. Furthermore, in the case of the recruitment and forced conscription of Burmese nationals, the levels of desertion were considerable and a significant unknown number are thought to have perished in the harsh environment of the Thai-Burma border. This tragic summary of the cost of this construction constitutes a major reason for visiting Kanchanaburi. However, the interpretation and content of this tragic history receives mixed treatment at a variety of sites across the city.

\section{Results: Kanchanaburi and its World War Two Heritage Attractions}

As previously indicated, the city comprises a number of attractions associated with this period of its history and these provide one of the primary reasons for visitation. All of the sites associated with this period of the destinations' tragic history were visited and operators contacted to request interviews as part of the fieldwork (see full listing below). 


\begin{tabular}{|l|l|l|l|}
\hline Title of Attraction & Operator & $\begin{array}{l}\text { Paid / Non Paid } \\
\text { Admission }\end{array}$ & Location \\
\hline $\begin{array}{l}\text { Thailand-Burma Railway } \\
\text { Centre }\end{array}$ & TBRC Co Ltd & Paid Admission & City \\
\hline The JEATH War Museum & $\begin{array}{l}\text { Wat Chaichumpol } \\
\text { Temple, Kanchanaburi }\end{array}$ & Paid Admission & City \\
\hline $\begin{array}{l}\text { Arts Gallery and War } \\
\text { Museum }\end{array}$ & Private Company & Paid Admission & City \\
\hline $\begin{array}{l}\text { Kancahanaburi War } \\
\text { Cemetery }\end{array}$ & $\begin{array}{l}\text { Commonwealth War } \\
\text { Graves Commission }\end{array}$ & Free Admission & City \\
\hline $\begin{array}{l}\text { Chungkai War Cemetery } \\
\text { Commonwealth War } \\
\text { Graves Commission }\end{array}$ & Free Admission & 5 Km West of City \\
\hline $\begin{array}{l}\text { Hellfire Pass Memorial } \\
\text { Burma-Thailand railway }\end{array}$ & $\begin{array}{l}\text { Australian War Graves } \\
\text { Commission }\end{array}$ & Free Admission & $\begin{array}{l}70 \text { Km North West } \\
\text { of the City }\end{array}$ \\
\hline
\end{tabular}

Table 3.0 : Kanchaburi Visitor Attractions and Sites associated with the Second World War.

The interviews generated a range of responses to the range of topic areas identified for discussion below built around a free flowing data base of questions and prompts

- Purpose of Operation and Ownership

- Nature of Experience on Offer

- Scale and Profile of Audience attracted

- Dwell Time

- Repeat Visitation

- Revenue and Profitability / use of funds generated

The nine individuals interviewed ranged from government and charity employees to owner / operators of what they described as commercial visitor attractions. For the cemetery and memorial sites the focus was on remembrance, sacrifice and understanding the narrative. The more commercial exploitation of such sites was seen as less acceptable.

In almost all cases levels of visitation was approximated and data pertaining to precise visitation was not shared. Visitation profiles were overwhelmingly international with Thai, Myanmar and Burma 
nationals constituting the minority of visitors and exhibiting the lowest dwell time. The majority of those visiting the sites (where interviews were undertaken) were ; Australian, UK, Netherlands and US visitors. In these cases visitors varied between being totally independent, part of a locally purchased tour or part of a more organised coach based tour. Dwell times for visitors of Australian, UK, Netherlands and US origins were significant on average 90 minutes but in many cases in excess of 120 minutes. There was a low instance of repeat visitation, evident normally where there was a direct family association with the site; although for all operators this was a declining consumer segment. Education visitation by local, regional and national schools constituted a minority visitation element at all sites. The use of funds raised by more commercial operators was extremely sensitive and discussion was limited. In the case of charities the contributions raised was utilised for maintenance, dealing with depreciation, extending and renewal of interpretation or used as a fund for local community education or development areas in nearby villages and towns.

The key sites also include: the 'Bridge over the River Kwai', a non-paid admission, metal railway bridge to the north west of the centre of town which is still operational and serves as a major attraction for international tourists. Whilst it is not gated or staffed its appeal is considerable. Its fame is linked primarily to filmic heritage and specifically a Hollywood narrative from; 'the Bridge on the River Kwai' directed in 1957 by David Lean. This film achieved no less than seven academy awards, despite its limited historical and geographical legitimacy. It catalysed the 'Bridge on the River Kwai' mythology; which, as its narrative grew became more acceptable and simpler to access than historical record. The current bridge, located in Kanchanaburi constitutes a re-representation of heritage. The Thai-Burma Railway was composed of many bridges, developed by forced labour (Allied prisoners and Asian Labourers) across the length of the route from Bang Pong (Thailand) to Thanbyuzayat (Burma). The Thai-Burma railway traversed some $416 \mathrm{kms}$ across rugged relief that required frequent bridges and cuttings. The bridge which tourists visit in the city of Kanchanaburi, is 
neither authentic nor historically pivotal. Like the river its identity has been changed to provide a past that can be more easily commodified and exploited. As Beattie $(2015,7)$ pointedly summarised:

"There was no bridge over the River Kwai. In fact there was no River Kwai."

The Thai authorities to satisfy visitor demand, changed the name of the river from Maeklaung to Kwai and the Thai-Burma railway never crossed the Khwae Noi tributary, that later achieved erroneous attention as the River Kwai. In reality, much farther north, near the Thai-Burma border the same railway crossed a tributary of the Khwae Noi; the Song Khalia River. It was in the British POW camp at the Song Khalia crossing that some of the worst excesses of the forced construction period occurred. It is probable, that this site inspired the initial 1954 book by Pierre Boule, that in turn catalysed the film (see Boulle, 1954). However, this forced labour camp was but one of approximately 55 that are recoded on the length of the route (Australian-Thai Chamber of Commerce, 2011). This route comprised numerous bridges and many POW camps. However, the filmic record has undoubtedly influenced the appeal of the destination, the development of its attractions and activities, constructing and re-representing destinations and sites (McCannell, 1976). Beeton (2016) in her appraisal of Film-induced tourism (2016) cites case after case, where impacts of representation in all forms of filmic and televisual media are shown to positively impact on visitation and destination awareness. 


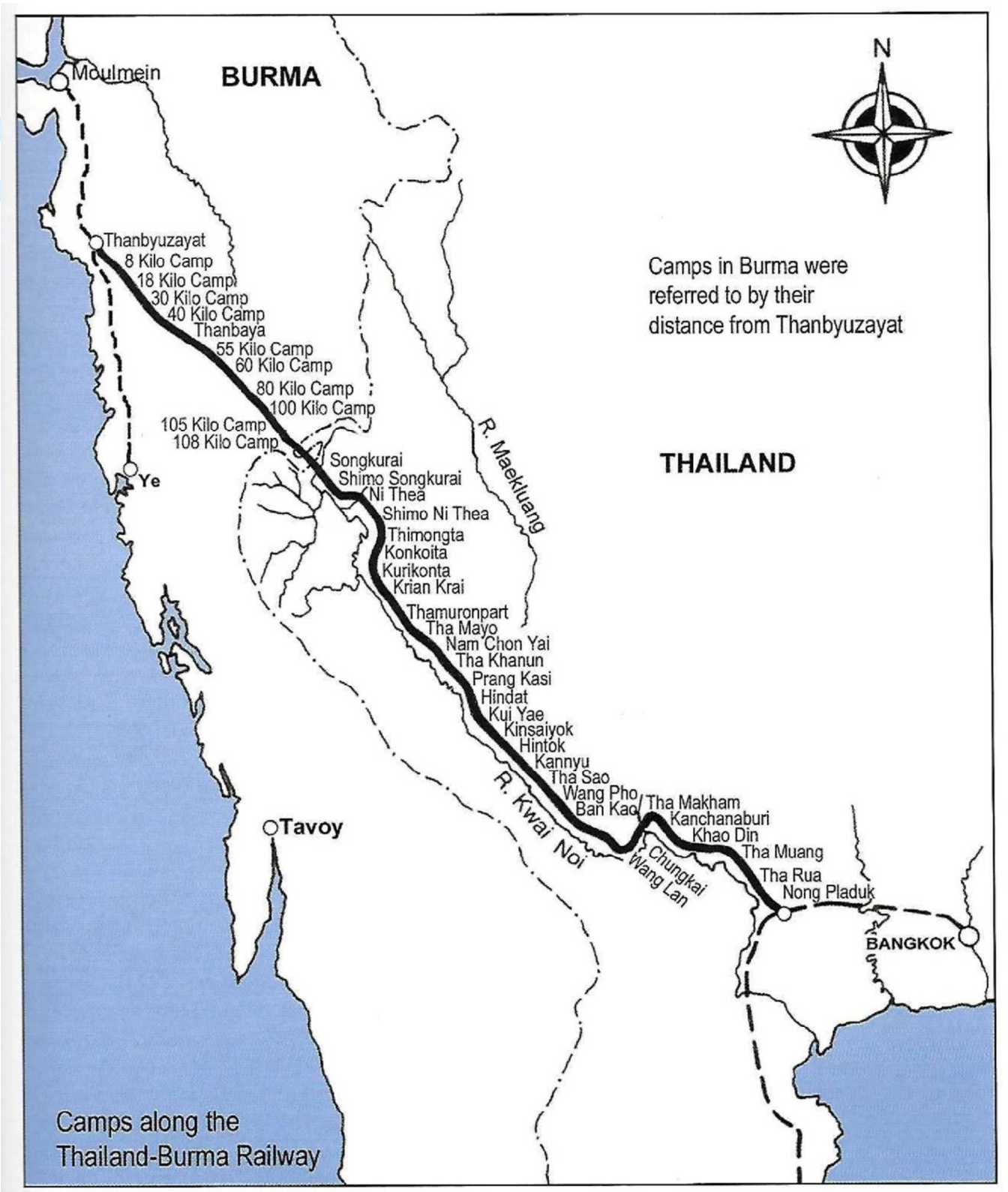

\section{Diagram 2.0: Location of POW and Forced Labour Camps on Thai-Burma Railway 1942-43 (Source:}

\section{Australian- Thailand Chamber of Commerce, 2011)}

The bridge at Kanchanaburi whilst originally built by the Asian labourers and Allied prisoners of war, traversed the River Maeklaung (renamed Kwai) and constitutes a further misrepresentation of the 'past'. The bridge is of steel construction rather than the wooden trestle bridge featured in the 
Bridge on the River Kwai (1957) film. Such wooden trestle bridges were the dominant construction type utilised on the Thai-Burma railway although as Beaumont (2009) noted many were demolished or lost following the cessation of World War Two hostilities.

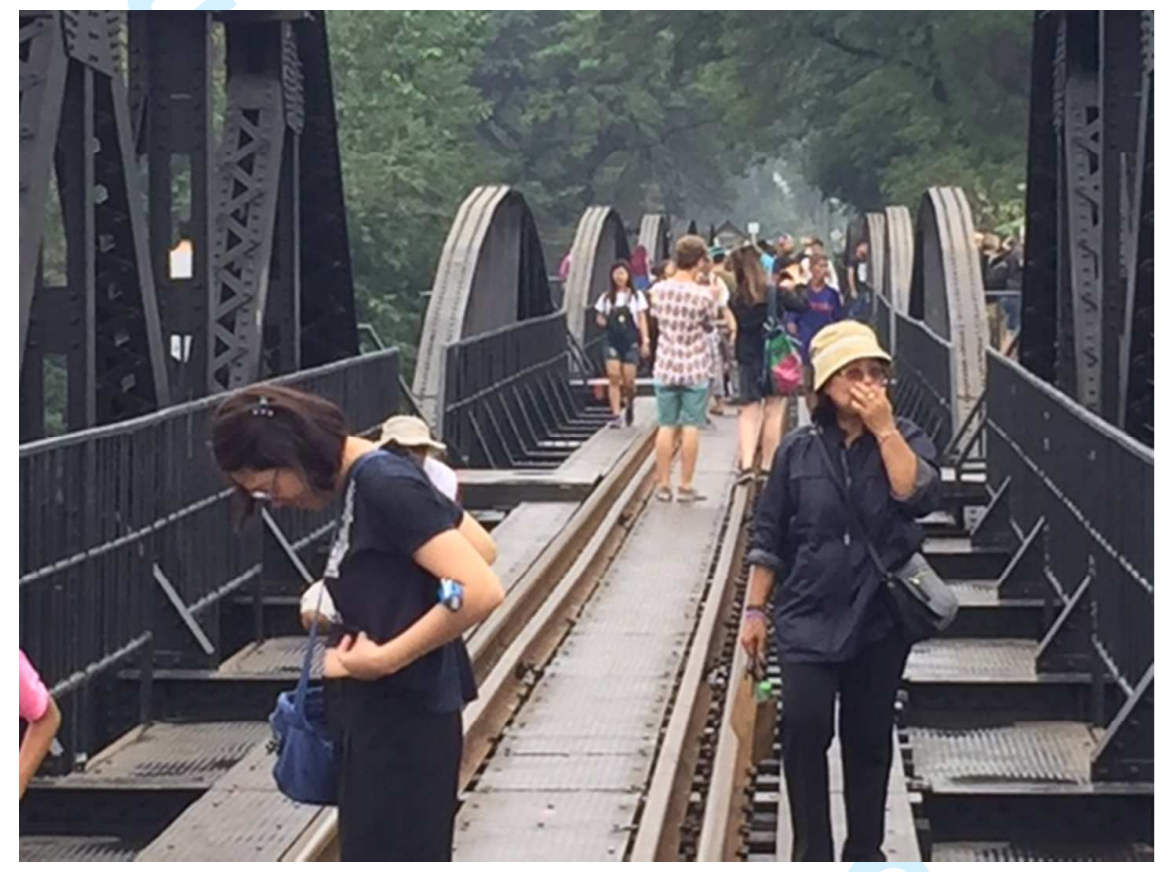

Photograph 1.0 : Tourists visiting 'Bridge on the River Kwai', Kanchanaburi, Thailand (Source J J Lennon ).

The impact of this augmented historical reality was catalysed by the filmic narrative of the Bridge of the River Kwai. This clearly has parallels in other destinations with a dark history. In 1981, a generation were reintroduced to the genocide of the Khmer Rouge, through the Roland Jaffe film; the Killing Fields. This filmic narrative provided a link to a true story and an abridged consideration of the complex cause of this barbaric regime's rise to power. The Killing Fields film, has an eponymously titled tourist attraction in the Cambodian capital; Phnom Penh. Whilst this constitutes a significant and well visited site, (second only in visitor numbers to the Khmer temple complex of Angkor Wat), it 
fails to effectively or accurately educate visitors about the scale of this genocide. For example, the single Killing Field attraction in Phnom Penh fails to highlight that almost 350 such sites existed across Cambodia during the murderous period of Khmer Rouge control in Cambodia (1975-9). Furthermore, the later loss of such heritage and historical evidence since 1979 is a further omission, appropriately tragic in its own context. Despite these facts visitation continues to grow as Riley et al noted:

"...locations need not be beautiful nor the storylines positive in order to attract visitors" (Op cit, 932).

Indeed, the pursuit of historical accuracy has rarely been the motivation of visitors. As Seaton and Hay (1989) recorded in their analysis of the impact of the impact of the film Braveheart on Scottish Tourism. Visitors were motivated to visit Scotland to experience and visit locations featured in the film, even though much of it had been filmed in Ireland, because of a more accommodating national tax regime. Interestingly, the same tourists would often then continue on to or revisit Ireland, to experience the 'faux' heritage sites which were the in fact 'authentic' film locations.

In the case of Kanchanaburi, the bridge is now a major attraction in the heart of the city where tourists of all nationalities visit and cross, in a seemingly endless stream of guided and independent tours. According to Beaumont (2012), this particular site offers for some:

“... displaced significance- that is a site that lacks heritage authenticity being invested with an emotional power at the level of individual memory or popular culture..."(Op cit 23)

However, this bridge is distant from historical fact and geographical location. Indeed, like some of the related attractions in the city, historical accuracy has been lost as war time heritage is exploited 
and loosely interpreted or ignored. This leads at best to dilution and at worst to inaccuracy. The represented history of the Thai-Burma railway has also been at least partially oriented towards a narrative of Allied loss. Indeed, in the majority of the attractions in Kanchanaburi, the Asian loss is minimised and the 'appropriation' of the narrative is evident. In the case of the JEATH museum ( the name is an abbreviation of; Japan, England, America, Australia, Thailand and Holland), the orientation towards an Allied narrative is dominant. The museum structure is a replica POW hut and the interpretation though amateurish is focussed around the conditions, work regime, diet, disease and sickness the allied prisoners experienced. The much larger Asian sacrifice remains undocumented at this location. Interestingly, this museum was established in 1977 by the chief abbot of the Wat Chaichumpol, in Muang, near Kanchanaburi. The content and interpretation of the museum is interestingly selective. For example, the introductory orientation makes claims which are hard to substantiate and difficult to comprehend (see below).

"The word JEATH also replaces the word Death because it sounds too horrific. The JEATH museum is a very important part of the history of Death Railway which will complete your visit to the River Kwae Bridge (sic)." (JEATH War Museum, 2016, 5)

The Art Gallery and War Museum in Kanchanaburi, presents a 'Bridge on the River Kwai' narrative with a disjointed consideration of selected historical figures of World War Two. These elements are combined with; a Miss Thailand fashion museum, an ore and jewellery set of displays along with a range of defunct and rusting contemporary helicopters and small passenger aircraft (non-military). The museum is constructed in the style of a Chinese temple and contains a large variety of unconnected artefacts. The museum does comprise some authentic World War Two artefacts which include; deteriorating photos and sketches, poorly constructed life size tableaux of prisoners of war, and a range of 'interpretive' notices such as that illustrated below: 


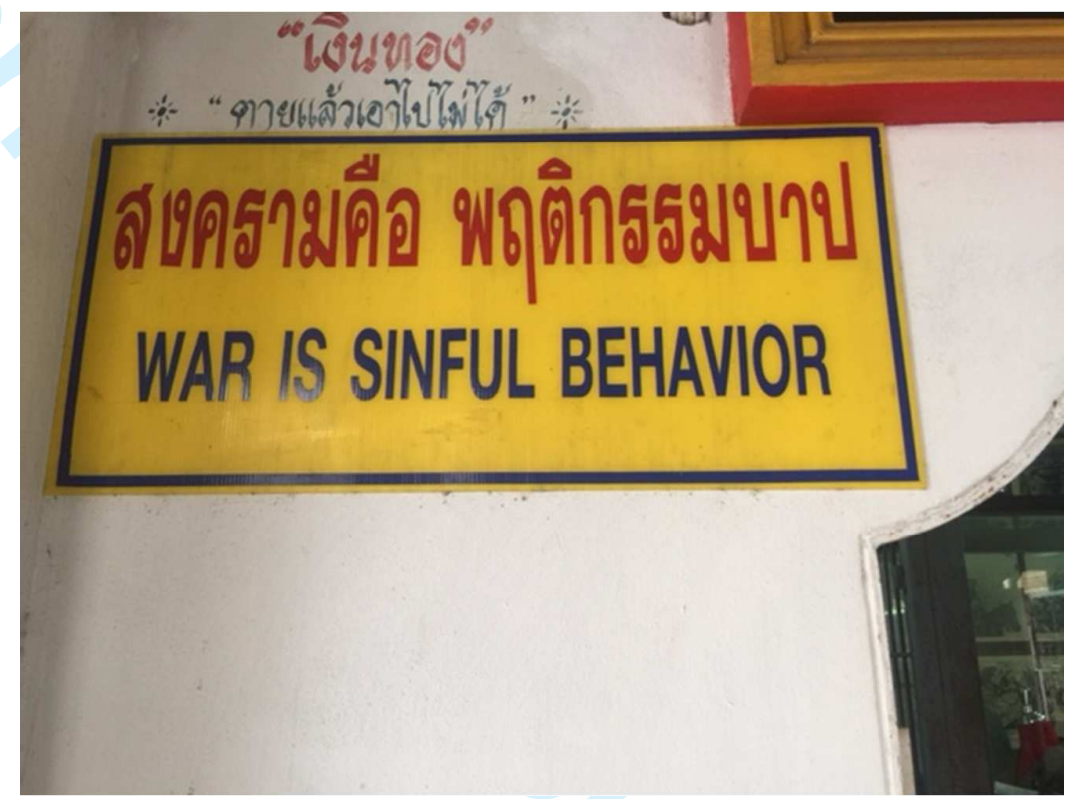

Photograph 2.0 : Typical Interpretation; Arts Gallery and War Museum, Kanchanaburi (Source: J J Lennon)

This private museum also venerates the original Chinese developer and his family in a shrine like space on the upper level. The museum also displays, in a glass case, the remains of a number of prisoners of war with the following interpretation;

"In this glass monument, the remains of 104 of the prisoners who worked as labourers during World War Two are kept on the second level and the remains of another two are kept on the third level, making a total of $106 "$ (see below) 


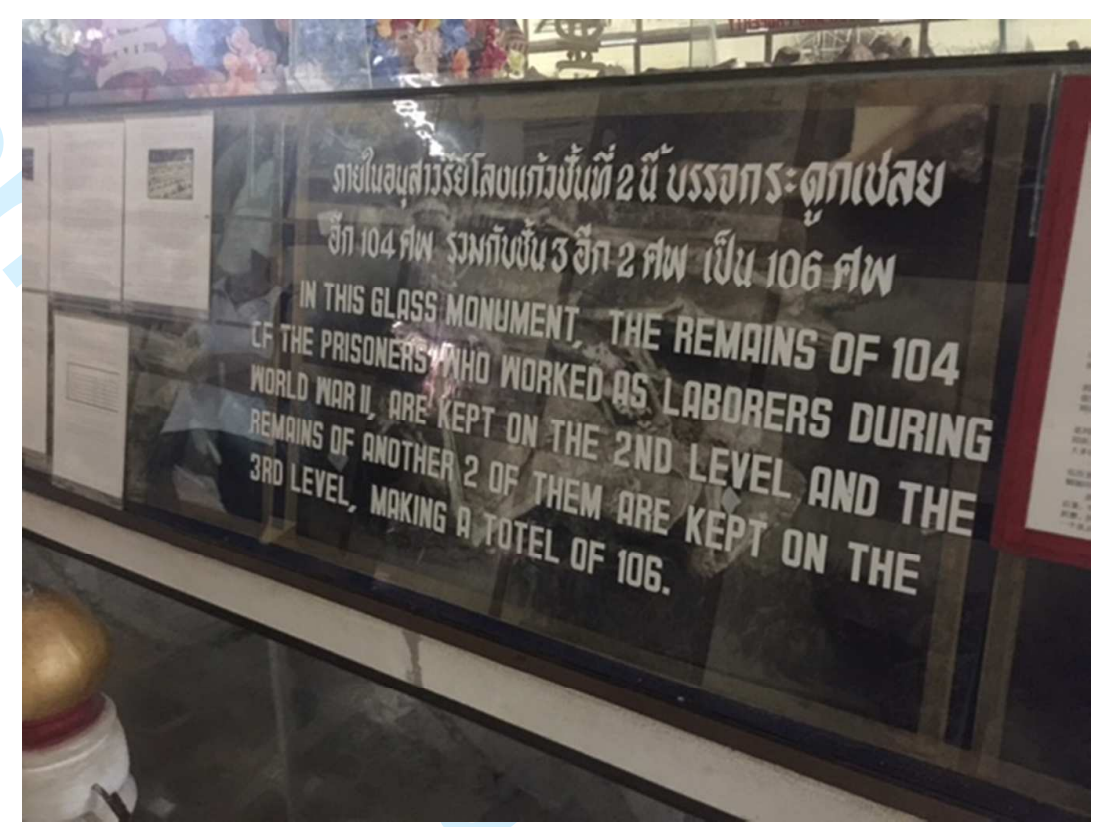

Photograph 3.0: Display of Human Remains: Arts Gallery and War Museum, Kanchanaburi (Source

\section{: J J Lennon)}

The quality of conservation in this museum is limited and Beaumont (2012) has suggested that these are Romusha remains but the situation is unclear.

In contrast, two related attractions, seek to relate a more authentic and historically defensible approach to the Thai-Burma railway. They are; the Hellfire Pass Memorial, Burma-Thai Railway and the Thailand-Burma Railway Centre. The latter opened in 2003, and is a visitor, research and documentation centre. It is located within Kanchanaburi, and its development is associated with Ronald Beattie, an ex-Australian army civil engineer, who has researched the Burma-Thai Railway since the early 1990s. Beattie has lobbied for conservation funds and following assistance from the Netherlands government, the Thailand-Burma Railway Centre, is now the major repository for artefacts and documentary evidence of the development and human cost of the railway. It provides a research and information service for those interested in tracing former prisoners of war and those involved in the construction. The interpretive content is deliberately non-partisan and based on 
donated and collected evidence, and a narrative which provides quantification of the full cost of construction in terms of Allied and Asian lives. This site also highlights the positive role of some Thai nationals in relation to the Prisoners of War. The exhibition features the interventions of; Mr K Gardiner (Siam Architects Imports Co), Mr E Heath (Borneo Co), Mr R Hempson (Anglo-Siam Corporation), Nai Boonpong Sirivejjabhandu and Nai Lee Soon, who were all associated with the ' $V$ ' corporation. These were a network of those opposed to the excesses of the Japanese 'occupation' of Thailand. They were responsible for passing money and medicines to POWs. Whilst undoubtedly heroic and important, it is a small part of the wider narrative.

Hellfire Pass Memorial, Burma-Thai Railway is the other notable heritage site that deals with the tragic past of this place. However, its construction was not without controversy and the nature of the multiple narratives of this place and how they changed since the initial consideration of the site in the 1980s have been documented at length by Beaumont (2012). This analysis probes how the range of nationalities were represented and charts the range of agendas and interest groups involved in the complex interplay of remembrance of captivity and conflict. This site is located $80 \mathrm{~km}$ north west of Kanchanaburi on land owned by the National Security Command (i.e. the Thai Army). This location is historically important, since it saw some of the worst excesses of the Japanese captors. However, this is also an important relationship between tenant and land owner, and constitutes an 'enclave' of quality heritage interpretation that remains dependent upon the Thai government's understanding and cooperation. As the site leaflet introduction to the memorial intimates:

"The Memorial provides an important educational function for the people of Thailand and visitors from Australia and other countries. The memorial stands as an enduring symbol of the close relationship between Thailand, Australia and those nations whose citizens worked on the BurmaThailand railway." (Australian Government, 2016, 4) 
The site is synonymous with the section of the rail route between Konyu and Hintok, which saw a major concentration of work on the railway construction between 1942-43 involving approximately 2,000 Australian and British prisoners (Australian Government, 2016). At this site, the excavation of soil and rock was carried out with limited machinery and predominantly by hand. Prisoners mainly used; hammers, drills, picks and shovels to remove rock. As production timescales became critical to Japanese engineers, productivity was increased, at great human cost ( Hearder, 2009). Shifts were extended from 12 to 18 hours, with the workplace lit by wood fires and oil pot lamps. This gave the impression of fires in a 'hell like' location, hence the application of the title 'Hellfire Pass' by the Prisoners (Australian-Thai Chamber of Commerce, 2011). In 1995, the Australian Government provided A\$ 1.6 million (Austrian Dollars) for the development of a substantial memorial centre and related visitor infrastructure to commemorate the events of the Railway construction. The interpretation of this site makes strong use of the audio testimony of Prisoners of War, in a selfguided tour. The visitor centre element incorporated illustrated and narrative based interpretation within the Memorial. It is deliberately not built around artefacts and has a clear focus on remembrance and learning, that provides due weighting to the extent of Asian as well as Allied losses.

\title{
Memory, memorial and re-representation; Hell fire Pass and beyond
}

\author{
It is apparent that in some cases memory remains contested and selective in aspects of the World \\ War Two heritage displayed in the city and environs of Kanchanaburi. The context of incarceration, \\ forced labour, atrocity is overlaid with competing memories of differing national groups. However, \\ this city offers a range of contrasting narratives for visitors and tourists, who may have limited
}


understanding of the competing sensitivities and agendas present. This incarcerated and forced workforce laboured mercilessly in monsoon conditions without adequate accommodation, food, clothing, medicine, clothing or footwear (Kinvig, 1992).In the absence of appropriate medicines and medical care, diseases such as; malaria, beri-beri, tropical ulcers, dysentery, cholera, general toxaemia and pellagra took their toll. This along with the cruelty and violence administered by the Japanese and Korean guards all contributed to the high fatality rates that characterised the construction phase (Kinvig, 1992). However, as Beaumont (2012) has recorded the site of Hellfire Pass is:

“...vulnerable to charges of selective and nationalistic representation and is inherently dissonant with local memories and cultural practices. Hence the sustainability of such heritage is fragile, dependent upon diplomatic negotiation and a continuing perception on the part of the host country that the heritage development is to its economic and political benefit." (op cit, 21)

The potential for the controversy in relation to content and interpretation within this site was considerable. Indeed, the potential impact on diplomatic and economic relations between Thailand and Japan was a concern during the site evolution and remains contentious as the Australian government wishes to make further investment in the site form 2017 onwards (Lennon 2017). The site and content also risks drawing attention to the Thai co-operation with the Japanese during World War Two; a period that receives limited coverage in other Thai museums. The co-operation agreement of 1942 between Japan and Thailand and the reality of Japanese occupation sits uncomfortably with narratives of nationalism and self-reliance (Blackburn, 2010). The distant Thai past of empire and conquest, may present a more acceptable history for the purpose of nationhood. However, selective interpretation is also accompanied by commercialising elements. In the case of the city of Kanchanaburi, this is illustrated each year with a son et lumiere performance that relates the 'history' of the 'Bridge on the River Kwai'. This visitor entertainment focuses on the allied 
bombing of the 'bridge' in 1944-45, and the civilian loss recorded. This lights and firework show attracts thousands of viewers generating significant economic impact at a local level. This spectacle and commercial exploitation of the 'River Kwai' narrative from T-shirt and souvenirs to resorts utilising the River Kwai as a destination marker, evidence how an increasingly distant interpretation of the past can be capitalised upon.

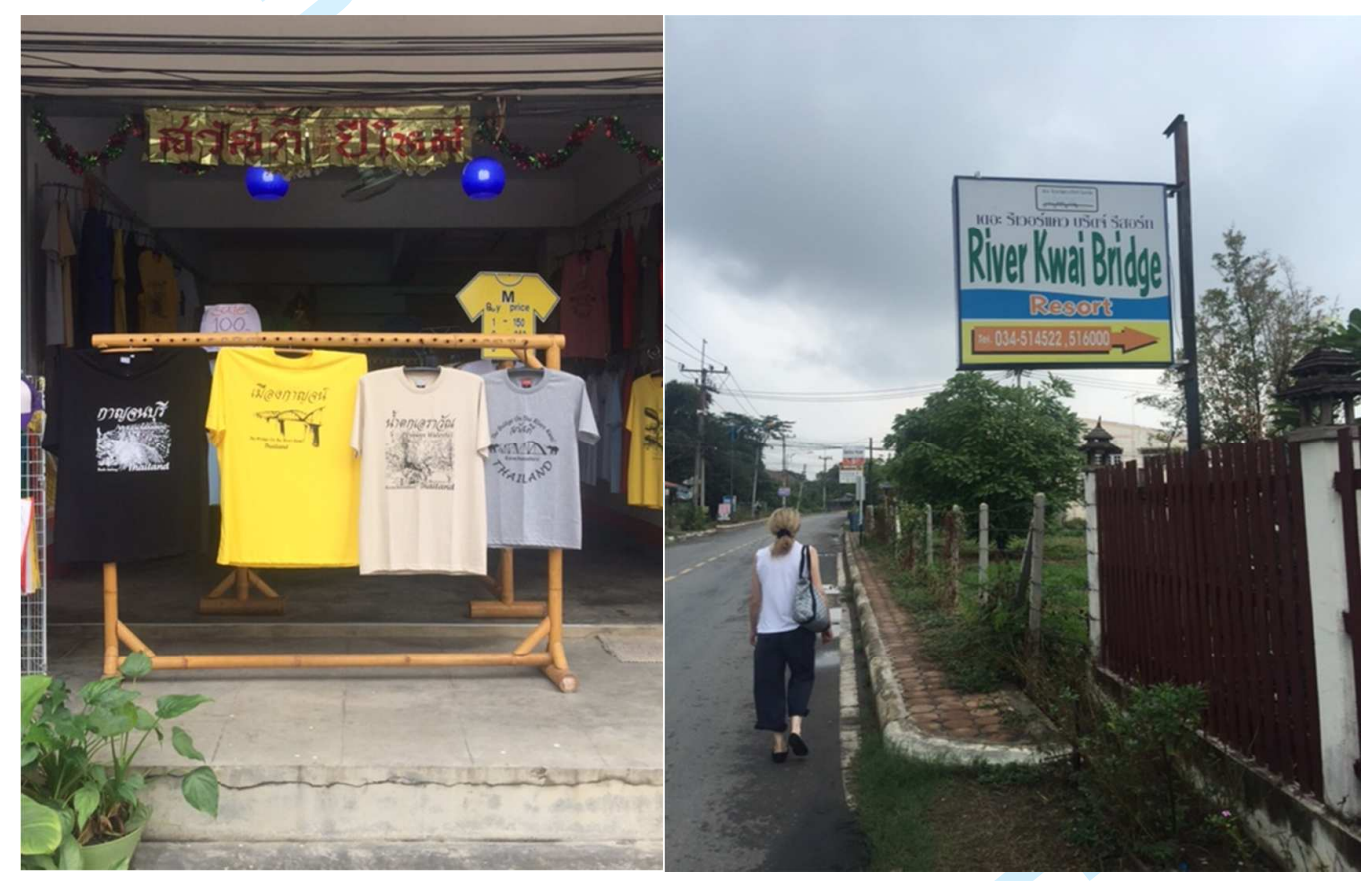

Photograph 4.0: River Kwai Bridge T-Shirt Merchandise and Resort Names, Kanchanaburi (Source:

\section{J J Lennon)}

Kanchanaburi offers a selective appraisal of the past. At least some of its attractions are located within a context of heritage that is neither neutral nor accurate. It is contingent on the political and cultural context of the national location. Heritage in such a context can be constructed, represented and re-represented to assert the primacy of national and political identity. The narrative is at one level appropriated by some of those with access to; tangible heritage, memories and artefacts. At a 
second level; the main World War Two graveyards, the visitor is overawed by the scale of loss. Yet, this belies the unmarked and unrecorded loss of the so-called Romusha. The table below records burials and estimated deaths at Chungkai and Kanchanaburi cemeteries in Thailand and Thanbyuzayat in Myanamar.

\begin{tabular}{|l|l|l|l|l|l|}
\hline Nationality & $\begin{array}{l}\text { POW / } \\
\text { Labourers }\end{array}$ & $\begin{array}{l}\text { Chungkai } \\
\text { Cemetery }\end{array}$ & $\begin{array}{l}\text { Kancahanaburi } \\
\text { Cemetery }\end{array}$ & Thanbyuzayat & TOTAL Deaths \\
\hline British & $30,000+$ & 1,384 & 3,568 & 1,588 & 6,540 \\
\hline Dutch & $18,000+$ & 313 & 1,896 & 622 & 2,831 \\
\hline Australian & $13,000+$ & - & 1.362 & 1,348 & 2,710 \\
\hline Malaysian & N/A & 37 & 104 & 79 & 220 \\
\hline Indian & N/A & 6 & 12 & 15 & 33 \\
\hline Unknown & - & - & 35 & 114 & 149 \\
\hline American & $700+$ & & $\begin{array}{l}\text { Remains } \\
\text { Repatriated }\end{array}$ & $\begin{array}{l}\text { Remains } \\
\text { Repatriated }\end{array}$ & 133 \\
\hline Subtotal & $\mathbf{6 1 , 0 0 0}$ & $\mathbf{1 , 7 4 0}$ & $\mathbf{6 , 9 7 7}$ & $\mathbf{3 , 7 6 6}$ & $\mathbf{1 2 , 6 1 6 +}$ \\
\hline $\begin{array}{l}\text { Asian } \\
\text { Labourers }\end{array}$ & $\mathbf{2 0 0 , 0 0 0 +}$ & & & & $80,000+$ \\
\hline Japanese & $\mathbf{1 5 , 0 0 0}$ & & & & \\
\hline TOTAL & $\mathbf{2 7 5 , 0 0 0}$ & & & & $\mathbf{9 4 , 0 0 0 +}$ \\
\hline
\end{tabular}

Table 4.0: Burials, Recorded and Estimated Deaths on the Burma-Thai Railway (Source: AustralianThai Chamber of Commerce, 2011)

During World War Two the Japanese Forces recorded the deaths of allied prisoners and allowed burial and marking of graves. Such record keeping and understanding was not extended to Asian labourers. Whilst it is understandable that these are fundamentally Allied War Graves, this reaffirms that remembrance of war is at one level political. The celebration and development of heritage shapes and sustains narratives of political legitimacy and identities (Gegner and Ziino, 2012). The physical manifestation of war memorialization in areas such as; cemeteries, uses distinct semiotic and aesthetic strategies to represent a sanctioned and acceptable interpretation of war. However, 
these are not simply the narratives of elite groups (cf Hall, 1992) but rather they absorb a multiplicity of war narratives. The narrative of the Asian Labourers, whilst represented in Hellfire Pass and the Thailand-Burma Railway Centre, is not the dominant interpretive context. This remains largely an interpretation of Allied loss, Allied struggle and ultimately an Allied victory. Heritage is contingent on the agencies that realise the narrative. This takes place in visitor centres and attractions and is sustained with funding by governments or commercial endeavour. As Eyal (2004) concurs, memory is neither immutable or given, heritage is selectively interpreted, constructed and reconstructed, represented and re-represented to assert national, religious, personal and cultural identities.

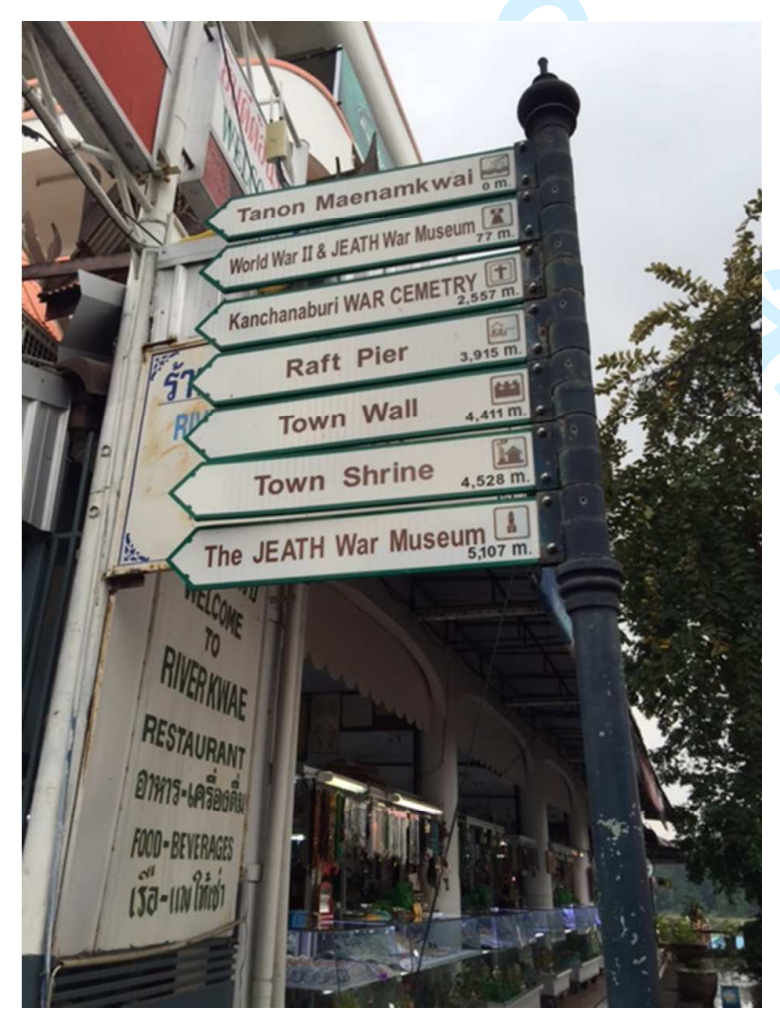

Photograph 5.0: Visitor Orientation, Kanchanaburi, Thailand (Source: J J Lennon) 


\section{Conclusions}

The city of Kanchanaburi is defined by a heritage that has changed over time. Many factors imbue the meanings and content of a city. This is a function of a plethora of competing Influences and agendas; political, economic, cultural, demographic and historical. Yet this urban destination is at least partly defined by the Dark history of World War Two. The critical mass of attractions focussed on the 'Bridge of the River Kwai' and the history of the construction of the Thai - Burma Railway provide destination awareness and have been utilised in urban marketing and individual product marketing whether in accommodation, retail, attractions or events. The narrative of some of these products remains problematic. Operators of tourist sites, such as visitor attractions; that constitute for some visitors a major learning experience (cf Lennon and Foley, 2000) have to be aware that they have potential to influence the historical, social and cultural meanings represented (Smith, 2006). The selection, interpretation and conservation of elements of the past are critical in understanding what is considered and how it is represented (Ashworth, 2008).

The visitor attraction sites considered in Kanchanaburi provide multiple narratives around World War Two events. They offer a range of content driven by influences as diverse as simple commercial gain to the complex interaction of political, economic and ideological agendas (cf Gegner, 2012). In each case interpretation can be used to articulate heritage through objects, artefacts, audio recording, place or imagery. These elements exist in environment(s) of their creation; the World War Two heritage of Kanchanaburi is developed in a nation that has only a selective acceptance of its role in this conflict. Historical memorialization remains embedded in interests that are global, commercial, ideological but rarely neutral. The interpretation of the Thai- Burma Railway and the narrative of the many victims associated with the construction merit respect and sensitive commemoration. 


\section{Further Research and Practical Insight}

This paper provides a foundation for further consideration of how such contested dark heritage is viewed not least by visitors and users. Development of research in this area would provide a valuable source of data on; consumer profiles, motivations and orientation. Relating this data to nationality and origin would provide useful comparative data to that offered by operators and managers of key attractions. Furthermore, the prevalence of social and digital media as primary tourist information source could be measured against the continued (and possibly declining) importance of the filmic narrative. Furthermore, deeper evaluation of nature and content of interpretation is merited given the range of approaches and content observed. At a political and policy level the treatment of this part of Thai history and the degree of sensitivity around interpretation is linked to how a nation confronts its difficult past. More thorough evaluation of treatment in national media and education curriculum also merits review. Urban heritage is an important element of urban destination marketing and evaluation based around core themes of transparency, openness, respect for the past and sensitive treatment of tragic events offer direction for application and evaluation in other urban contexts. 


\section{References}

Adie B A, Amore A and Hall CM (2017) Urban tourism and urban socialist and communist heritage: beyond tragedy and farce ? in International Journal of Tourism in Cities 3,3 (pp291-304), Emerald Insight

Ashworth G (2008) The memorialisation of Violence and Tragedy: Fuman trauma as Heritage in Graham B and Howard P (2008) (Eds) The Ashgate Research Companion to Heritage and Identity, (231-244) Ashgate, Farnham

Ashworth, G. (1996). Holocaust tourism and Jewish culture: The lessons of Krakow- Kazimierz. In M. Robinson, N. Evans, and P. Callaghan (Eds.). (1996). Tourism and culture - Towards the 21st century. Athenaeum Press, London

Australian Government (2015) Hellfire Pass Memorial Burma-Thailand Railway, Department of Veterans' Affairs, Office of Australian War Graves

Australian-Thai Chamber of Commerce (2011) HellFire Pass Memorial Thailand-Burma Railway, Australian Thai Chamber of Commerce

Beattie R (2015) The Death Railway, TBRC Co, Kanchanaburi, Thailand

Beaumont J (2012) Hellfire Pass Memorial Museum , Thai-Burma Railway Museum, (pp19-41) in

Beaumont J (2009) Contested Transnational Heritage: the demolition of Changi Prison in International Journal of Heritage Studies 15(4) (294-316)

Beaumont J (2005) Prisoners of War in Australian National Memory (184-194) in Moore B and

Beech J (2009) Genocide tourism in Sharpley, R. and Stone, P. (Eds.). (2009). The darker side of travel London, Routledge.

Beeton S (2016) Film-induced Tourism (2 ${ }^{\text {nd }}$ Edition), Channel View Publications, Bristol

Botterill, D., and Jones, T. (2010). Tourism and crime. Oxford, UK: Goodfellow Publishing.

Dann, G., \& Seaton, A. (Eds.) Slavery contested heritage and thanatourism. Binghamton, NY: Haworth Hospitality Press.

Eyal G (2004) Identity and Trauma: Two forms of the will to memory in History and Memory, 16 (1) $(5-36)$ 
Foley M and Lennon J J (1996) JFK and dark tourism; a fascination with assassination in International Journal of Heritage Studies 2,4 (pp198-211) Taylor and Francis

Hately Broad B (2005) (Eds) Prisoners of War; Prisoners of Peace Captivity, Homecoming and Memory in World War Two, Berg, Oxford

Blackburn K (2010) War Memory and Nation Building in South East Asia in South East Asia Research, $18(1),(5-31)$

Boulle P (2007) The Bridge over the River Kwai, Presidio Press Random House, New York

Gegner M and Ziino B (Eds) (2012) The Heritage of War, Routledge, London

Beeton S (Ed) (2016) Film-induced Tourism, Channel View Publications, Bristol

Gegner M (2012) War monuments in East and West Berlin: Cold War symbols or different forms of memorial in Gegner M and Ziino B (2012) The Heritage of War, (64-87) Routledge, London

Gegner M and Ziino B (2012) The Heritage of War, Routledge, London

Hall S (1992) Encoding, Decoding in S Hall, D Hobson A Lowe and P Willis (Eds) Culture, Media, Language, (128-138) London, Routledge

Hardie R (1983) The Burma-Siam Railway, Imperial War Museum, London

JEATH War Museum (2016) The JEATH War Museum, Kanchanaburi, Thailand, Kanchanaburi, Thailand

Kinvig C (1992) River Kwai Railway, Bressey's, London

Kratoska W (2005) Labour in the Malay Peninsula and Singapore under Japanese occupation in Kratoska P H (Ed) (2005) Asian Labour in the Wartime Japanese Empire; Unknown Histories, New York, East Gate Books

Lennon J. J. (2010). Dark tourism and sites of crime. In D. Botterill \& T. Jones (Eds.), Tourism and crime. Oxford, UK: Goodfellow Publishers.

Lennon J (2009) Tragedy and Heritage in Peril : The Case of Cambodia in Tourism Recreational Research (Vol 3 No 2 pp 116-123)

Lennon, J.J. and Foley, M. (2000) Dark Tourism - the Attraction of Death and Disaster, Continuum. (now in $4^{\text {th }}$ International Edition)

Lennon, J.J and Foley, M (1996) 'Editorial: Heart of Darkness' in the International Journal of Heritage Studies 2 (1) 195-197. 
Lennon J, and Smith H (2004) A Tale of Two Camps: Contrasting Approaches to Interpretation and Commemoration in the Sites at Terezin and Lety, Czech Republic in Tourism Recreation Research Vol.29 No.1 pp 15-25

Lennon J and Wight C (2007) Selective Interpretation and Eclectic Human Heritage in Lithuania in Tourism Management Vol 28 00519-529

Lowenthal D (1997) The Heritage Crusade and the Spoils of History, Cambridge University Press, Cambridge

McCannell D (1978) The Tourist: A new theory of the Leisure Class, Shocken Books, New York

Mitchell, M. (Ed.). (2007). Remember me constructing immortality-Beliefs on immortality, life and death. New York: Routledge.

Page S J and Hall C M (2002) Managing Urban Tourism, London, Prentice Hall

Philpott, C. (2016.) Relics of the Reich. York, UK: Trinners.

Reuters(2017) World News Thailand tourist numbers rise nearly nine percent in 2016

https://www.reuters.com/article/us-thailand-tourism/thailand-tourist-numbers-rise-nearly-ninepercent-in-2016-idUSKBN14P0QF

Riley R Baker D and Van Doren C (1998) Movie induced tourism in Annals of Tourism Research 25(4) (919-935)

Seaton, A. V. (1996). Guided by the dark; from thanatopsis to thanatourism. International Journal of Heritage Studies 2(4): 234-244.

Seaton, A. V., and Lennon, J. J. (2004). Moral panics, ulterior motives and ulterior desires: Thanatourism in the 21st century. In T. Singh (Ed.), New horizons in tourism: Strange experiences and stranger practices (pp. 63-82). Wallingford, UK: CABI Publishing.

Seaton A V and Hay B (1998) The marketing of Scotland as a tourism destination in MacLelland R and Smith R (1998) Tourism in Scotland, (209-239), International Thompson Press, London

Sharpley, R. and Stone, P. (Eds.). (2009). The darker side of travel. London: Routledge.

Skinner, J. (2012). Writing the dark side of travel. London: Berghahn Books

Smith L (2006) Uses of Heritage. Routledge, London

Stone, P. and Sharpley, R., (2008) Consuming dark tourism: A thanatological perspective in Annals of Tourism Research, 35(2), pp.574-595.

Stone, P.R. (2006) A dark tourism spectrum: Towards a typology of death and macabre related tourist sites, attractions and exhibitions in Turizam: znanstveno-stručni časopis, 54(2), pp.145-160.

Strange, C. and Kempa, M.(2003) Shades of dark tourism: Alcatraz and Robben Island in Annals of 
Tourism Research, 30(2), pp.386-405.

Thompson J (2002) The Imperial War Museum Book of the War in Burma 1942-1945, Macmillan, London

Tourism Authority Thailand (2016) Thailand reaps top global awards for three most popular tourist destinations in 2015 http://www.tatnews.org/thailand-reaps-top-global-awards-for-three-mostpopular-tourist-destinations-in-2015/

Tunbridge, J. E., and Ashworth, G. J. (1995). Dissonant heritage: The management of the past as a resource in conflict. Chichester, UK: John Wiley

UNWTO (2016) Tourism Highlights 2016 Edition

White, L., and Frew, E. (2012). Dark tourism and place identity: Managing and interpreting dark places. Oxford, UK: Routledge. 